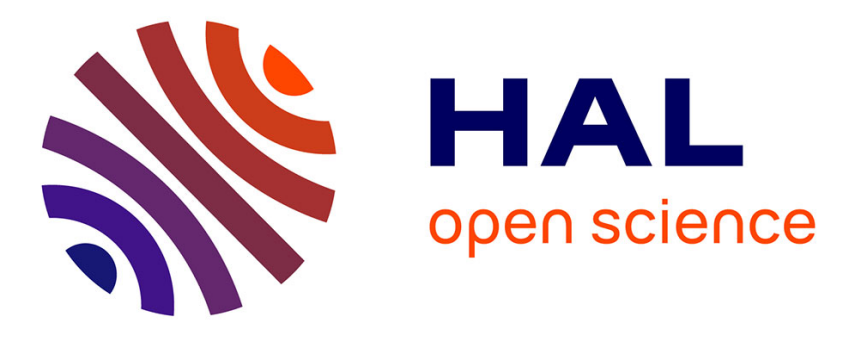

\title{
The robustness of ecological indicators to detect long-term changes in the macrobenthos of estuarine systems
}

Joana Patrício, João Magalhães Neto, Heliana Teixeira, Fuensanta Salas, João Carlos Marques

\section{To cite this version:}

Joana Patrício, João Magalhães Neto, Heliana Teixeira, Fuensanta Salas, João Carlos Marques. The robustness of ecological indicators to detect long-term changes in the macrobenthos of estuarine systems. Marine Environmental Research, 2009, 68 (1), pp.25. 10.1016/j.marenvres.2009.04.001 . hal00487744

\section{HAL Id: hal-00487744 \\ https://hal.science/hal-00487744}

Submitted on 31 May 2010

HAL is a multi-disciplinary open access archive for the deposit and dissemination of scientific research documents, whether they are published or not. The documents may come from teaching and research institutions in France or abroad, or from public or private research centers.
L'archive ouverte pluridisciplinaire HAL, est destinée au dépôt et à la diffusion de documents scientifiques de niveau recherche, publiés ou non, émanant des établissements d'enseignement et de recherche français ou étrangers, des laboratoires publics ou privés. 


\section{Accepted Manuscript}

The robustness of ecological indicators to detect long-term changes in the macrobenthos of estuarine systems

Joana Patrício, João Magalhães Neto, Heliana Teixeira, Fuensanta Salas, João Carlos Marques

PII: S0141-1136(09)00035-X

DOI: 10.1016/j.marenvres.2009.04.001

Reference: MERE 3328

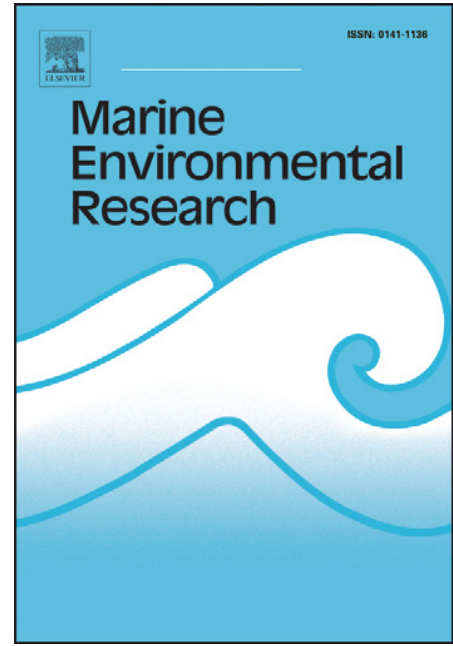

To appear in:

Marine Environmental Research

Received Date:

8 August 2008

Revised Date:

4 April 2009

Accepted Date:

7 April 2009

Please cite this article as: Patrício, J., Neto, o.M., Teixeira, H., Salas, F., Marques, o.C., The robustness of ecological indicators to detect long-term changes in the macrobenthos of estuarine systems, Marine Environmental Research (2009), doi: 10.1016/j.marenvres.2009.04.001

This is a PDF file of an unedited manuscript that has been accepted for publication. As a service to our customers we are providing this early version of the manuscript. The manuscript will undergo copyediting, typesetting, and review of the resulting proof before it is published in its final form. Please note that during the production process errors may be discovered which could affect the content, and all legal disclaimers that apply to the journal pertain. 
1 The robustness of ecological indicators to detect long-term changes in the macrobenthos of estuarine systems.

3

4

$7{ }^{1}$ IMAR- Institute of Marine Research, c/o Department of Zoology. Faculty of Sciences and Murcia. Spain.

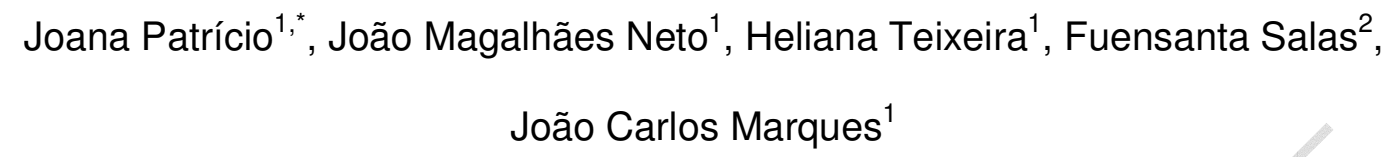

(1) 8 Technology. University of Coimbra. 3004-517 Coimbra. Portugal.
92 Department of Ecology and Hydrology. Faculty of Biology. University of Murcia. 30100-

\section{Abstract}

Accurate and reliable benthic quality indicators are in great demand following the recent developments and the strict time schedule for implementing the European Water Framework Directive. The Mondego estuary has experienced a progressive deterioration during the 1990's, followed by a partial ecological recovery due to restoration measures in 1997/1998. We have used the estuary as a model system to test the performance and robustness of a set of ecological indicators in highlighting the changes in the ecological state of intertidal areas. Over a period of 17 years (1985-2002), we calculated Margalef, Shannon-Wiener, Berger-Parker, Taxonomic Distinctness measures, AZTI's Marine Biotic Index, Infaunal Trophic Index, and Eco-Exergy based indices and tested differences across periods characterised by different anthropogenic disturbance. We combined temporal data within three periods: before, during and after disturbance, based on 
progressive information on the changes in the extended type of anthropogenic disturbance. Indices were then compared with biological and abiotic descriptors (macroalgae, macrophytes, benthic macrofauna, nutrients concentration, sediment grain size and total organic carbon). We found great disparity in the indicators ability to capture temporal changes, showing distinct performances at each site. At the $Z$. noltii site, only Margalef, Total Taxonomic Distinctness and the thermodynamically based indices captured temporal changes, despite giving higher values during the disturbance period. At the bare sediment site, Taxonomic Distinctness, ITI, Shannon-Wiener, Berger-Parker, $\mathrm{AMBI}$ and the $\mathrm{TBI}$ were able to distinguish between periods, in agreement with the differences observed analysing the macrobenthic assemblages. Furthermore, Taxonomic Distinctness was not robust enough to detect any temporal or spatial change. We thus suggest further research to understand the behaviour of ecological indicators, in view of their crucial importance for the management and protection of marine coastal areas.

Keywords: ecological indicators, benthic macrofauna, intertidal, ecological status, estuaries, Portugal

\section{Introduction}

\subsection{Background}

Ecological indicators are commonly used to provide synoptic information about the state of ecosystems. Most often they summarise information on the structure and/or functioning of ecosystems using a particular biological aspect or component of these ecosystems, such as diversity, productivity or environmental conditions (Salas et al., 
2006). In general, the application of ecological indicators is not exempt from criticism. Aggregation of different metrics results in oversimplification of the ecosystem under observation. Moreover, the choice of which ecological indicators to use should follow criteria based on the question we want to address and the theoretical background on which the indicator was created. Before being able to use an indicator it is thus necessary to establish its applicability and robustness for a set of conditions, by testing its consistency with the ecological expectation.

The implementation of the European Water Framework Directive (WFD) (EC, 2000), as well as the recent European Marine Strategy Directive 2008/56/EC (EC, 2008) require the use of well-founded ecological indicators, which has contributed greatly to develop this research field and stimulate analyses to establish indicators' applicability to a variety of ecosystems. Indeed, since 2000, numerous ecological quality assessment tools have been proposed by the European scientific community (e.g. Borja et al., 2004; Rosenberg et al., 2004; Bald et al., 2005; Simboura et al., 2005; Devlin et al., 2007; Muxica et al., 2007; Pinto et al., 2009). The WFD suggests that the water body ecological quality should be primarily determined by biological quality elements and then by hydromorphological and physicochemical quality elements.

The composition and structure of benthic macrofauna is one of the indicated biological quality elements to be used in transitional and coastal waters for quality status assessment. Benthic communities may detect the level of stress locally and integrate the recent history of stress, constituting a sort of memory for the system. Macrofauna are dominated by species with different mobility, life-cycle and tolerance to stress (Dauer, 1993), which covers the WFD demand of integrating differently sensitive species. The response of macrobenthic communities to several types of stress is well studied, based on multivariate analyses that take into account variations in species diversity and their relative 
abundance between perturbed and control sites (e.g. Pearson and Rosenberg, 1978, Warwick and Clarke 1993, Gray 2002). Based on this knowledge it is possible to determine a priori the ecological indicator behaviour and thus its appropriateness to detect changes in the variable of interest. The aim of our study was to test the performance and robustness of a large set of ecological indicators based on the composition and structure of macrobenthic communities.

A plethora of methodologies with hundreds of indices, metrics and evaluation tools are presently available (Borja \& Dauer, 2008; e.g. see summary in Diaz et al., 2004). An ecologically parsimonious approach dictates that investigation should place greater emphasis on evaluating the suitability of indices that already exist prior to developing new ones (Díaz et al., 2004). We thus selected a large set of ecological indicators of different types (Margalef, Shannon-Wiener, Berger-Parker, Taxonomic Distinctness measures, AZTI's Marine Biotic Index (AMBI), Word Infaunal Trophic Index (ITI), and Eco-Exergy based indices) and compared the status of two sites " $Z$. noltii site" and a "bare sediment" in the Mondego estuary (western coast of Portugal; 400' $\mathrm{N}, 8^{\circ} 50^{\prime} \mathrm{W}$ ) over a period of seventeen years. During this period, the estuary experienced changes in the type and severity of anthropogenic stress, which changed macrophyte distribution and macrofauna communities. We asked whether different ecological indicators were able to detect changes and whether these changes were in agreement with the differences observed analysing species composition of macrobenthic assemblages. Specifically, we tested for differences in the macrofauna composition and biological indicators between the periods during and after the major anthropogenic changes. We also assessed which ecological indicators were more robust in detecting these changes.

\subsection{Synopsis of human induced changes in the Mondego estuary ecosystem}


The Mondego estuary is a relatively small (860 ha) warm-temperate intertidal system.

At present, the entire catchment area contributes a large loading of nutrients and several chemicals into the system. Moreover, the estuary supports industrial activities, saltextraction, and aquaculture farms, and is located close to a tourism centre (Figueira da Foz). The estuary's terminal part is $7 \mathrm{~km}$ long and is $2-3 \mathrm{~km}$ across at its widest part, consisting of two arms, separated by the Murraceira Island (Fig. 1). The northern arm is deeper (5-10 $\mathrm{m}$ during high tide), constituting the main navigation channel and the harbour location. The southern arm is shallower (2-4 m during high tide), and is characterised by large areas of intertidal flats exposed during low tide (almost $75 \%$ of the total area of the southern arm). A detailed description of the system can be found in Cardoso et al. (2004) and Marques et al. (2007). A comprehensive study on the environmental quality of the Mondego estuary was carried out during the last two decades (Marques et al., 2007) and covered several quality elements (water quality, hydraulics and sediments dynamics, benthic intertidal and subtidal communities, $Z$. noltii beds and green macroalgal cover). Such analyses allowed detection increased eutrophication symptoms and ecological deterioration in the South arm since early 1990s, when the communication between the two arms was interrupted, increasing water residence time and nutrient concentration (Lillebø et al., 2005).

Since then, macroalgal blooms became more frequent and intense (mostly Ulva spp.) (e.g. Martins et al., 2001; Cardoso et al., 2004; Pardal et al., 2004; Leston et al., 2008) and have affected $Z$. noltii beds, reducing the area covered by the seagrass and the bodiversity and community biomass in the remaining meadow (Cardoso et al., 2008; Lillebø et al., 2005). Before the interruption, the $Z$. noltii covered 15 ha (in 1986), which decreased to 1.6 ha in 1993, when macroalgal blooms increased up to $415 \mathrm{~g} \mathrm{~m}^{2}$ (Fig. 2). In $1997 \mathrm{Z}$. noltii bed reached its lowest value (0.02 ha). Through time, such modifications promoted the emergence of a simplified trophic structure, which has been analysed in the existing 
126 literature (e.g. Dolbeth et al., 2007; Martins et al., 2005; Lopes et al., 2006; Patrício and

127 Marques, 2006). Since 1998, the system has started recovering, after the decrease in

128 freshwater discharge from the Pranto River and the limited re-establishment of 129 communication between the two arms (Marques et al., 2007; Leston et al., 2008; Cardoso 130 et al., 2008). Z. noltii meadow has began to recover and in 2005, it occupied an area of 131 about 4.2 ha.

\section{Material and Methods}

\subsection{Description of the database used}

Intertidal benthic communities were first sampled in 1985 (during winter) and 1986 (during summer). Subsequently, the community was regularly monitored from January 1993 to January 1996, and again from January 1999 to December 2002 once every two weeks from 1993 to 1996, and monthly from 1999 to 2002.

In all cases, sampling was conducted at two sites in the South arm (Fig. 1), within $Z$. noltii meadow, which persisted during early 1990s, and on an area where the Z. noltii has disappeared, now characterised by bare sediment. Each time and at each site, six replicate cores were taken to a depth of $20 \mathrm{~cm}(13 \mathrm{~cm}$ inner diameter and then pooled together for macrofauna analyses. Sediment was washed through a $500 \mu \mathrm{m}$ mesh sieve and animals preserved in $4 \%$ buffered formalin. Animals were identified to species level

147 and subsequently dried at $70^{\circ} \mathrm{C}$ for $72 \mathrm{~h}$ to estimate biomass as dry weight (DW) and ash 148 free dry weight (AFDW), after combusting samples for $8 \mathrm{~h}$ at $450^{\circ} \mathrm{C}$. 


\subsection{Hydrological changes and variation in macroalgal and macrophyte coverage} and biomass

Hydrologic changes in the Mondego estuary, following human interventions, have been assessed using technical reports, maps and aerial photographs. Samples of macrophytes and macroalgae were taken once every two weeks from January 1993 to January 1996, and subsequently, from January 1999 to December 2002, with a monthly periodicity. Six cores $(13 \mathrm{~cm}$ diameter to a depth of $20 \mathrm{~cm}$ ) were randomly taken from each site ( $Z$. noltii site and bare sediment site), during low tide. Macroalgal and macrophyte species were identified to the species' level, dried at $70^{\circ} \mathrm{C}$ for 48 hours and then combusted at $450^{\circ} \mathrm{C}$ for 8 hours to estimate biomass as AFDW. Additionally, the area of $Z$. noltii meadows was measured through aerial photographs and field campaigns (Marques et al., 2007).

\subsection{Ecological indicators}

\subsubsection{Description and calculation}

The following ecological indicators were calculated using the macrofauna database, for each site and time. Replicates within site and time were pooled.

1. The AZTI's Marine Biotic Index, AMBI, (Borja et al., 2000) is based on the proportion of five ecological groups to which the benthic species are allocated. The soft bottom macrofauna was divided into five groups according to their sensitivity as a function of an increasing stress (see Table 1 for details). The AMBI 4.0 software, freely available at http://www.azti.es, was used to calculate this index, using a species list of July 2006 and following Borja and Muxika (2005) guidelines. AMBI ranges from 0 to 7 , and a better quality trend would be indicated by a decrease on the index value (see Table 1). 
2. To estimate Taxonomic Diversity indices - Taxonomic Diversity, $\Delta$; Taxonomic Distinctness, $\Delta^{*}$ and Total Taxonomic Distinctness, $\mathbf{s} \Delta^{+}-$a hierarchical Linnean classification was used as a proxy for cladograms representing the relatedness of individual species. For each location, a composite taxonomy was compiled, five taxonomic levels were considered (species, genus, family, order, class and phylum) (Clarke and Warwick, 1998, 2001a) and the indices were calculated using PRIMER 5 (Software package from Plymouth Marine Laboratory, UK) (Table 1). Higher values of these indices suggest that, on average, the species in the assemblage are not closely related, being higher biodiversity.

3. The Berger-Parker, Margalef and Shannon-Wiener indices were also calculated (see Table 1 for details). The Berger-Parker takes values from 0 to 1 , with higher values corresponding to lower diversity. An increase on Margalef index is generally accepted as an indication of quality improvement. The $\log _{2}$ was used to compute the Shannon-Wiener; therefore the results were expressed in bits/individual and higher values correspond to higher diversity.

4. The Infaunal Trophic Index, ITI, was calculated following Codling and Ashley (1992). For each sample, the taxa contributing to the top $80 \%$ of the abundance have been allocated to trophic groups. In addition, in samples with ten or less identified taxa, all were taken into consideration for calculation purposes. Once generated, the list of the unclassified taxa was compared with the lists provided by Word $(1979,1990)$. Table 2 shows the Mondego estuary species' trophic classification. Values of the index vary from 0 to 100 with low values indicating degraded conditions. ITI values were used to classify areas of seabed into either "normal" (ITI values 100-60), "modified" (60-30) or "degraded" (30-0) (Bascom et al., 1978). 
5. Exergy expresses the work capacity relative to the same system but at thermodynamic equilibrium with its environment, which means that all the components would be inorganic at the highest possible oxidation state and homogeneously distributed at random in the system (no gradients). Of course exergy cannot be measured precisely, as the total internal energy content of a body cannot be measured exactly. Nevertheless, with regard to far from equilibrium systems (e.g. ecosystems), a reasonable approximation can be obtained if exergy is calculated only from the chemical potentials (which are in fact extremely dominant in ecosystems) (Jørgensen, 2000). This approximate measure can be called Eco-Exergy index (Marques et al., 1997). If the total biomass in the system remains constant through time, then the variation of Eco-Exergy will be a function of only the quality of the biomass (structural complexity) or, in other words, of the information embedded in the biomass, which may be called Specific Eco-Exergy. Both indices were calculated using macrofauna biomass data and $\beta$-values given by Jørgensen et al. (2005) according to the algorithm shown in Table 1.

\subsubsection{Criteria used to assess the ecological indicators' success/failure}

According to Borja et al. (2008), index validation should ideally include (1) testing of the index using an independent data set, different from the index development data set; (2) setting a priori correct classification criteria and/or (3) presentation of a strong a posteriori justification for use based upon best professional judgment. The first requirement was fulfilled using our own data set from two intertidal sites in the Mondego estuary. In order to assess the indices success or failure to discriminate the ecological quality status, two main criteria were used: 
1) The classification proposed by the index authors. High values of Margalef, ShannonWiener, Taxonomic distinctness indices, ITI and the thermodynamically based indices (TBI) indicate high ecological quality status. High values of Berger-Parker and AMBI indicate low ecological quality status (Table 1).

2) Determining the level of agreement provided by an index with best professional judgment. In our case study, the indices scores were compare with the existing knowledge about the ecological changes of the system (e.g. Marques et al., 1993, 2007; Pardal et al., 2000, 2004; Dolbeth et al., 2007; Cardoso et al., 2004, 2008; Lillebø et al., 2005, 2007; and the present study) according to ultimate causal stressors that had induced such changes (e.g. hydrology and eutrophication) and to other potential stressors (proximate causes) generated by changes in hydrology and eutrophication (e.g. changes in seagrass cover and biomass ( $Z$. noltii site); changes in the algal mats biomass (bare sediment site); nutrients levels; sediment grain size and total organic carbon (TOC).

\subsection{Statistical analysis}

\subsubsection{Univariate analysis}

One-way ANOVA, with time as fixed factor (2 levels: "during the interruption of flow between the North and South arms - 1993 to 1995" and "after the experimental opening of the connection between the two arms of the estuary- 2000 to 2002") and 30 and 29 replicates for Z. noltii site and bare sediment site, respectively, was used to test for temporal differences in each of the two sites (with respect to total abundance, total biomass, number of species, Margalef, Shannon-Wiener, Berger-Parker, Biotic Coefficient (AMBI), Taxonomic Distinctness indices, ITI, Eco-Exergy and Specific Eco-Exergy). The 
247 "before the interruption- 1985-1986" period was left out from this analysis due to it small

248 number of replicates. Data were checked for normality using the Kolmogorov-Smirnov test

249 and homogeneity of variances was assessed by the Levene's test. Data were transformed

250 when homoscedasticity assumption was not met. The analyses were performed using the

251 software package Minitab version 12.2. In each site, we expected no differences during

252 the years of interruption, which strongly increased eutrophication effects and

253 sedimentation, thus affecting $Z$. noltii and the post-management years.

254

255

256

257

258

259

260

261

262

263

264

265

266

267

268

269

270

\subsubsection{Multivariate analysis}

In order to examine the benthic macroinvertebrate communities' temporal dynamics in Mondego estuary South arm, a multivariate analysis was performed on biological data from the Z. noltii site and bare sediment site using the PRIMER 5.2.6 @) software (Software package from Plymouth Marine Laboratory, UK). Data of abundance were square root transformed prior to analysis in order to scale down the effects on the ordination of highly abundant species (Clarke and Warwick, 2001b). The Bray Curtis similarity matrix was calculated and used to generate a 2-dimensional plot with the non-metric multidimensional scaling (nMDS) technique (Clarke, 1993). The one-way ANOSIM test was performed to test for differences among time periods. Species contributing $70 \%$ to differences between periods were identified using similarity percentages (SIMPER; Clarke, 1993).

\section{Results}

\subsection{Changes in macrofauna assemblages}


In both sites, there was a significant decline in total macrofauna abundance in the

272

273

274

275

276

277 "after the experimental opening" period (1-way ANOVA, Z. noltii site: $F_{1,58}=12.59, \mathrm{p}<$ 0.01; bare sediment site: $F_{1,56}=24.06, p<0.01$ ) (in seagrass bed, from 1993 to 1995: $35181-249966$ ind $\mathrm{m}^{-2}$; from 2000 to 2002 : $5785-120375$ ind $\mathrm{m}^{-2}$; in the bare sediment site, from 1993 to 1995: 6515 - 167554 ind $\mathrm{m}^{-2}$; from 2000 to 2002: 3430 - 28324 ind $\mathrm{m}^{-2}$ ) (Fig. 3A). Whereas the total biomass, in the Z. noltii site, was significantly higher "during the interruption" period (1-way ANOVA, $F_{1,58}=7.63, \mathrm{p}<0.01$ ), ranging from 58 to $158 \mathrm{~g} \mathrm{~m}^{-}$ 2. In the bare sediment site, the total biomass was significantly higher after the implementation of preliminary management measures (range $20-75 \mathrm{~g} \mathrm{~m}^{-2}$ ) (1-way ANOVA, $\left.F_{1,56}=20.59, \mathrm{p}<0.01\right)($ Fig. $3 \mathrm{~B})$. In both sites, more species were present "during the interruption" period compared to "after the experimental opening" period. (Fig. 3C) (1-way ANOVA, Z.noltii site: $F_{1,58}=77.23, \mathrm{p}<0.01$; bare sediment site: $\left.F_{1,56}=15.65, \mathrm{p}<0.01\right)$. Generally, the $Z$. noltii site supported more species than the bare sediment site (in the Z.noltii site, from 1993 to 1995: $14-40$ species; from 2000 to 2002: 9-25 species; in the bare sediment site, from 1993 to 1995: 7-28 species; from 2000 to 2002: 7-20 species).

In both sampling sites, the results of the one-way ANOSIM test showed significant differences $(p<0.001)$ between the two periods. Nonetheless, the $Z$. noltii site had higher Global $R$ value than the bare sediment site (Global $R=0.42$ and 0.32 , respectively). The nMDS showed that the "after the experimental opening" period is closer to the reference points, particularly in the Z. noltii site (Fig. 4).

The SIMPER analysis showed that in the Z. noltii site, Hediste diversicolor, Hydrobia ulvae, Scrobicularia plana, Cyathura carinata, Tubificidae, Alkmaria romijni, Heterosmastus filiformis, Capitela capitata, Cerastoderma edule and Chaetozone setosa were the species responsible for the separation between periods (Table 3 ). During the period of works and closure of the channel, the abundance of some polychaete species 
(A. romijni, H. filiformis, C. capitata and C. setose), of Tubificidae and $H$. ulvae

297 dramatically increased as compared to the period before disturbance (1986) and also to the period following mitigation measures (1998-2002) (Table 3).

\subsection{Ecological indicators}

In both sites, Margalef (Fig. 5A) exhibited significant differences between the two time periods considered (1-way ANOVA, Z. noltii site: $F_{1,58}=58.70, p<0.01$; bare sediment site: $\left.F_{1,56}=12.29, \mathrm{p}<0.01\right)$, presenting unexpected higher values "during the interruption" period. Overall, Margalef was always higher in the Z. noltii site than the bare sediment site. The qualitative measure based on the presence/absence of species, TTD

(Fig. 5B), showed similar behaviour (1-way ANOVA, Z. noltii site: $F_{1,58}=76.82, p<0.01$; bare sediment site: $\left.F_{1,56}=15.12, \mathrm{p}<0.01\right)$. the Taxonomic Distinctness between periods (Fig. 5C), $(p>0.05)$, and the index was not larger in the $Z$. noltii compared to the bare sediment site.

The Taxonomic Diversity (Fig. 5D) and ITI (Fig. 5E) were unable to detect temporal changes in the $Z$. noltii site, but, as theoretically expected, exhibited lower values "during

313 the interruption" period at the bare sediment site (1-way ANOVA, $F_{1,56}=10.67, \mathrm{p}<0.01$ and $F_{1,56}=6.49, \mathrm{p}<0.01$, respectively). Both indices were lower at $Z$. noltii site, differing from the behaviour that we could predict based on the authors classification and our own

316 knowledge regarding the system. According to Bascom et al. (1978), ITI classified the

317 benthic community in the bare sediment site community as a "slightly modified" to "normal".

The Shannon-Wiener (Fig. 5F) values were higher in the bare sediment site, because of the dominance of $H$. ulvae in the Z. noltii site (almost $90 \%$ of the total abundance). 
321 While no significant differences were detected between the pre- and post-management

322 periods in the reference site (1-way ANOVA, $F_{1,58}=0.14, p=0.71$ ), in the bare sediment

323 site, the values were significantly higher "after the experimental opening" period (1-way

324 ANOVA, $F_{1,56}=9.68, p<0.01$ ). As expected, the Berger-Parker dominance (Fig. 5G)

325 showed the opposite behaviour, with higher values in the $Z$. noltii site, again due to $H$.

326 ulvae's dominance. In the bare sediment site, the dominance significantly decreased after

327 the implementation of the management plan (1-way ANOVA, $F_{1,56}=12.82, p<0.01$ ).

328 A significantly higher AMBI value (Fig. $5 \mathrm{H})$ was found "during the interruption" period

329 at the reference site (1-way ANOVA, $F_{1,58}=5.91, p<0.02$ ), indicating worse ecological

330 conditions during this time period. In the bare sediment site, no differences regarding the

331 pre- or post restoration periods were detected (1-way ANOVA, $F_{1,56}=2.53, p>0.05$ ). This

332 index showed similar values in both sites.

333 In the Z. noltii site, Eco-Exergy and Specific Eco-Exergy (Fig. $5 \mathrm{I}$ and J) were 334 significantly higher "during the interruption" period (1-way ANOVA, Eco-Exergy: $F_{1,58}=$ 335 8.66, $p<0.01$; Specific Eco-Exergy: $\left.F_{1,58}=56.85, p<0.01\right)$. In the bare sediment site, 336 these indices showed the opposite behaviour, with significantly higher values "after the 337 experimental opening" period (1-way ANOVA, Eco-Exergy: $F_{1,56}=25.24, p<0.01$; Specific 338 Eco-Exergy: $F_{1,56}=4.8, p<0.03$ ), indicating higher biomass structure and information 339 embedded in it. The indices had higher values in the $Z$. noltii site than in the bare sediment 340 site, following the behaviour that we would predict based on a priori established criteria.

\section{Discussion}


Our analyses on the long-term changes in the composition of macrofauna assemblages confirmed the previous studies (e.g. Dolbeth et al., 2007; Marques et al., 2007; Cardoso et al., 2008) and highlighted that the system seems to be recovering from the environmental changes occurred during the 1990s. At both sites, during the 19931995, the total dissolved inorganic nitrogen in the water column was higher than "after the experimental opening period" (Leston et al., 2008), the macroalgae assemblages were dominated by Ulvaceans, the $Z$. noltii cover and biomass reached their lowest values (Marques et al., 2007) and the abundance of the opportunistic species increased. After 1997/1998, the macrofauna and macrophyte assemblages showed a partial recovery towards the reference situation.

The selected ecological indicators are based upon community characteristics that are typically part of, or inherent to, the diversity of definitions of biotic integrity that include elements of species diversity, abundance, energy-flow-food web structure, maintenance of complexity and self-organization (Borja and Dauer, 2008). Therefore, according to the classification proposed, we would expect significantly higher values for Margalef, Shannon-Wiener, Taxonomic Distinctness measures, ITI, Eco-Exergy and Specific EcoExergy; $\mathrm{AMBI}$ and Berger-Parker should present significant lower values during the posmanagement period, at both sites. In the $Z$. noltii site, only AMBI reflected the ecological expectation, of a community with higher abundance of opportunist species "during the interruption" period. Margalef, TTD and the TBI indicated higher diversity and biomass structure/information "during the interruption" period, indicating that this community was apparently able to obtain some benefit from the existing conditions (higher nutrient input, lower water residence time). In the bare sediment site, with the exception of Margalef and TTD, all ecological indicators able to detect significant differences between time periods, 
performed as initially projected, indicating a better ecological status "after the experimental opening" period.

Furthermore, even if hydrology and eutrophication (both water column related), were probably the major drivers "shaping" South arm environmental conditions, the two study sites were differently affected by distinct stressors resulting from these drivers. The bare sediment site, characterised by sandy sediments, which have not supported rooted macrophytes for more than 15 years, lower organic matter content (mean $3.0 \% \pm 1.14$ ) and lower water-flows $\left(0.8-1.2 \mathrm{~m} \mathrm{~s}^{-1}\right)$ has been regularly covered by extensive algal mats (e.g. Lillebø et al., 2005; Dolbeth et al., 2007; Marques et al., 1997, 2003, 2007; Cardoso et al., 2008). These macroalgal blooms have well-documented effects, causing dramatic changes in sediment chemistry, nutrient release, rates of oxygen consumption and accumulation of metal sulfides and $\mathrm{H}_{2} \mathrm{~S}$ in sediment pore waters. These shifts are profound changes in habitat quality for invertebrate assemblages (e.g. Pearson \& Rosenberg, 1978; Raffaelli et al 1998; Cloern, 2001; Patrício \& Marques, 2006). On the other hand, the $Z$. noltii site, represents a distinct complex and heterogeneous habitat with particular physical and chemical conditions, characterised by muddy sediments covered with rooted macrophytes, higher organic matter content (mean $6.2 \% \pm 1.76$ ), higher waterflow velocity (1.2-1.4 $\left.\mathrm{m} \mathrm{s}^{-1}\right)$ (e.g. Dolbeth et al., 2007) and supporting a higher diversity of species (Cardoso, 2004). Knowing that the direct and indirect responses to changes in hydrology and nutrient enrichment are expressed in varying degrees in different habitats (Cloern, 2001), and taking into consideration the effect of site-specific operative stressors, we have considered $Z$. noltii site as representing a better ecological condition. Therefore, we would expect higher values for Margalef, Shannon-Wiener, Taxonomic Distinctness measures, ITI, Eco-Exergy and Specific Eco-Exergy in the reference site; AMBI and Berger-Parker would present the opposite behaviour. In fact, only Margalef, TTD and TBI 
followed the behaviour that we could predict based on our knowledge of the system (Fig.

396

4). Taxonomic Distinctness and AMBI presented similar values at both sites, indicating that these two metrics may be of limited efficacy in understanding the environmental conditions being investigated. $\mathrm{AMBI}$ values were dominated by $H$. ulvae abundance. As numerous estuarine species, this gastropod belongs to ecological group III, which comprises species tolerant to an excess of organic matter enrichment, a widespread stressor in transitional systems. Such explanation is supported by considering that Shannon-Wiener and BergerParker indices indicated that the $Z$. noltii site was of lower quality than the bare sediment. These indices are based on measures of equitability and dominance, and can vary unexpectedly if one species becomes dominant, as is the case of $H$. ulvae. Indeed, excluding $H$. ulvae from the dataset resulted in opposite results. $H$. ulvae is a very mobile species that may migrate during low tide towards areas more protected and with high food availability, as is the case of $Z$. noltii site. Therefore, more attention should be paid to the ecology and distribution of species to decrease the probability of giving an erroneous classification based on a species with high mobility. Furthermore, it should be noticed that in estuaries species dominance occurs more often than on coastal systems, even in relatively pristine conditions, due the large natural variability of environmental parameters. According to Constanza et al. (1992) and Elliot and Quintino (2007), in these ecosystems, the "positive effect" of natural environmental variability is shown as the ability of some organisms, which can tolerate the adverse and variable environmental conditions, to capitalise on the lack of inter-specific competition and thus achieve high population densities. Therefore, caution should be taken when interpreting equitability and dominance results based in estuarine macrobenthic assemblages.

Following Word (1990), ITI showed a higher value in the bare sediment site, where the sediment organic matter content was lower. However, in the Z. noltii site the sediment 
organic matter has a natural source (macrophyte primary production). For that reason, the metric is not correctly capturing the environmental conditions being investigated. Moreover, ITI is difficult to apply in environmental studies once determining the organisms' diet may become reasonably problematic. Generally, the real diet (studied observing stomach content) is difficult to establish, and can vary from one population to another among the same taxonomic entity (e.g. H. filiformis was classified by Brown (1985) as subsurface deposit feeder and as surface detritus feeder by Word (1990)).

According to our study, it seems that the ecological indicators response was not always temporally and spatially consistent (Table 4). These results are quite interesting, raising further questions.

It is well known, that estuaries are particularly challenging due to strong spatial, seasonal and inter-annual variations of environmental characteristics that influence benthic communities (Chainho et al., 2007). Apart from salinity regime, plant presence/absence, sediment grain size and organic matter content, the hydrological conditions, such as flood and drought periods, may have great impact in communities and thus on diversity measures (Pearson and Rosenberg, 1978; Gray, 1997; Raffaelli et al., 1998; Cloern, 2001; Salas et al., 2006; Chainho et al., 2007; Dolbeth et al., 2007; Cardoso et al., 2008; Teixeira et al., 2008).

In summary, we may say that although hydrology and eutrophication were the major drivers, other ultimate causal factors, probably also played a role during the study period, making it difficult to unambiguously distinguish the anthropogenic disturbance effects from the natural temporal wide-scale variability. In any case, the ecological indicators' results were constrained to the type and magnitude of the drivers' combined effect that occurred at either or both sites during the study period. Therefore, caution must be taken interpreting values isolated from the ecological community context. 


\subsection{Scientific implications and limitations of the study}

This paper laid out some of the history of anthropogenic modifications and sketched

a brief image of the ecological changes over the considered timeframe (derived partially from previously reported literature). In addition, many readers have pondered comparisons among all of the new indices that seem to continuously emerge (e.g. Díaz et al., 2004; Labrune et al., 2005; Aubry \& Elliot, 2006; Quintino et al., 2006; Dauvin et al., 2007; Blanchet et al., 2008). The present study compared several ecological indicators (all using benthic macrofauna) to the image of change that can be cast through a set of measurements on alterations in water quality, hydraulic/sediments, benthic invertebrate and plant/algal communities, and spatial distribution. Even if this broad comparison has been made in the past, given the European initiatives to use indices to monitor estuarine challenging to see such different predictions from the diverse indices, given that the same data were used (albeit in different ways, but that was the aim). Blanchet et al. (2008), testing five biotic indices (AMBI, BENTIX, Shannon-Wiener diversity, BQI and BOPA) in two semi-enclosed, sheltered coastal ecosystems and in one transitional water body the Mondego estuary subtidal assemblages, using four indices (Margalef, ShannonWiener, AMBI and W-Statistic). 
Notwithstanding, it is obvious for us, that the perfect way to compare indices would

470 be to (ideally) set up an ecological situation, in as controlled a manner as possible, in which one knew the "precise, accurate and totally clear answer" already and where strong putative gradients were selected for validation testing (e.g. Borja et al., 2000; Quintino et al., 2006). Nevertheless, the available ecological tools will have to work in "existent" ecosystems and available datasets. In our case study the ecological indicators diagnostic ability was only tested in two sites: a "Z. noltii site" and a "bare sediment site" during two different time periods, characterised by different levels of impact. We did not cover the five categories featured within the WFD (bad, poor, moderate, good and high). Therefore, this study only addresses two conditions and for that reason provides a limited assessment. Clearly, with other case-studies, further steps will have to be done to fulfil the WFD requirements. The second phase of the European WFD Intercalibration exercise will certainly be critical, particularly for transitional systems. Even so, it is our conviction that initially the proposed ecological indicators should be able to give the correct assessment in this case, particularly, when some of these metrics are being selected and combined into multimetric indices used to assess the ecological quality status all over Europe with obvious legal implications. We truly agree that without a sound and obvious ecological foundation, an index will not be policy-relevant and therefore difficult to use to make policy choices (Borja and Dauer, 2008), thus the results must be justifiable and scientifically defensible. Experiences gather from different ecosystems, distinct geographical ranges, various hydrological regimes, and diverse pressure types are vital and urgent. 
Relevant conclusions can be taken from our study: (1) Taxonomic Distinctness did not

494

495

496

497

498

499

500

501

502

503

504

505

506

507

508

509

510

511

512

513

514

515

516

517

detect temporal and spatial changes; (2) ITI did not detect spatial changes largely because estuarine macrofauna shows diet plasticity and is able to adapt its trophic role; (3) The equitability and dominance measures were totally influenced by the presence of a common species with high mobility, (4) The best distinction between sites was given by Margalef, TTD and TBI, (5) The indicators ability to capture temporal changes was different in each site, revealing habitat-dependency and (6) although some ecological indicators have been effective in differentiating the two time periods, not all have behaved consistently with ecological expectation. These considerations are crucial for management, once an indicator is expected to respond to a particular pressure and lead to a human response to reduce environmental impacts through the systems' driving forces, with all the social and economic repercussions of that action.

\section{Acknowledgments}

The present study was carried out in the scope of WADI (INCO-CT-2005-015226), EXTREMIS (III/36/2008) and RECONNECT (PTDC/MAR/64627/2006) research projects. It was supported by the FCT (Portuguese National Board of Scientific Research) through three grants (SFRH/BPD/26604/2006, SFRH/BPD/41701/2007, SFRH/BD/24430/2005). This work had the institutional support of INAG-National Water Institute (Portugal). Authors wish to thank two anonymous referees for their critical review of the first version of the manuscript and for their useful comments. We would also like to sincerely thank F. Rossi for helping us to improve the quality of the manuscript. Special thanks to all who assisted us, at any moment, during field and laboratory work. 


\section{References}

Ansell, A.D., Comely, C.A., Robb, L., 1999. Distribution, movements and diets of macrocrustaceans on a Scottish sandy beach with particular reference to predation on juvenile fish. Marine Ecology Progress Series 176,115-130.

Aubry, A., Elliot, M., 2006. The use of environmental integrative indicators to assess seabed disturbance in estuaries and coasts: application to the Humber Estuary, UK. Marine Pollution Bulletin 53, 175-185.

Bald, J., Borja, A., Muxika, I., Franco, J., Valencia, V., 2005. Assessing reference conditions and physico-chemical status according to the European Water Framework Directive: A casestudy from the Basque Country (Northern Spain). Marine Pollution Bulletin 50, 1508-1522.

Barnes, R.S.K., de Villiers, C.J., 2000. Animal abundance and food availability in coastal lagoons and intertidal marine sediments. Journal of the Marine Biological Association of the United Kingdom 80,193-202.

Bascom, W., Mearns, A.J., Word, J.Q., 1978. Establishing boundaries between normal, changed and degraded areas. In: Annual Report, 1978. Southern California Coastal Water Research Project, p. 81-94.

Berger, W.H., Parker, F.L., 1970. Diversity of planktibuc Foraminifera in deep sea sediments. Science 168, 1345-1347.

Borja, A., Franco, J., Pérez, V., 2000. Marine Biotic Index to establish the ecological quality of softbottom benthos within European estuarine and coastal environments. Marine Pollution Bulletin 40 (12), $1100-1114$.

Borja, A., Franco, J., Valencia, V., Bald, J., Muxika, I., Belzunce, M.J., Solaun, O., 2004. Implementation of the European water framework directive from the Basque country (northern Spain): a methodological approach. Marine Pollution Bulletin 48, 209-218.

Borja, A., Muxika, I., 2005. Guidelines for the use of AMBI (AZTI's Marine Biotic Index) in the assessment of the benthic ecological quality. Marine Pollution Bulletin 50, 787-789.

Borja, A., Dauer, D.M. 2008. Assessing the environmental quality status in estuarine and coastal systems: comparing methodologies and índices. Ecological Indicators 8: 331-337.

Brown, A.C., 1985. The effects of crude oil pollution on marine organisms: a literature review in the South African context: conclusions and recommendations. South African National Science Programmes Report No. 99, $33 \mathrm{p}$.

Cardoso, P.G., Pardal, M.A., Lillebø, A.I., Ferreira, S.M., Raffaelli, D., Marques, J.C., 2004. Dynamic changes in seagrass assemblages under eutrophication and implications for recovery. Journal of Experimental Marine Biology and Ecology, 302: 233-248. 
Cardoso, P.G., Bankovic, M., Raffaelli, D., Pardal, M.A. 2007. Polychaete assemblages as indicators of habitat recovery in a temperate estuary under eutrophication. Estuarine Coastal and Shelf Science 71, 301-308.

Cardoso, P.G., Raffaelli, D., Lillebø, A.I., Verdelhos, T., Pardal, M.A. 2008. The impact of extreme flooding events and anthropogenic stressors on the macrobenthic communities' Dynamics. Estuarine Coastal and Shelf Science 76, 553-565.

Chainho, P., Costa, J.L., Chaves, M.L., Dauer, D.M., Costa, M.J., 2007. Influence of seasonal variability in benthic invertebrate community structure on the use of biotic índices to assess the ecological status of a Portuguese estuary. Marine Pollution Bulletin 54: 1586-1597.

Clarke, K.R., 1993. Non-parametric multivariate analyses of changes in community structure. Australian Journal of Ecology 18, 117-143.

Clarke, K.R., Warwick, R.M., 1998. A taxonomic distinctness index and its statistical properties. Journal of Applied Ecology 35, 523-531.

Clarke, K.R., Warwick, R.M., 2001a. A further biodiversity index applicable to species lists: variation in taxonomic distinctness. Marine Ecology Progress Series 216, 265-278.

Clarke, K.R., Warwick, R.M., 2001b. Change in marine communities: an approach to statistical analysis and interpretation, $2^{\text {nd }}$ edition. PRIMER-E: Plymouth.

Cloern, J.E., 2001. Our evolving conceptual model of the coastal eutrophication problem. Marine Ecology Progress Series 210, 223-253.

Codling, I.D., Ashley, S.J., 1992. Development of a biotic index for the assessment of pollution status of marine benthic communities. Final report to SNIFFER and NRA. NR 3102/1.

Constanza, R., Norton, B.G., Haskell, B.D., 1992. Ecosystem health: new goals for environmental management. Island Press, Washington, D.C., USA.

Dauer, D.M., Maybury, C.A., Ewing, R.M., 1981. Feeding behaviour and general ecology of several spionid polychaetes from the Chesapeake Bay. Journal of Experimental Marine Biology and Ecology 54 (1), 21-38.

Dauer, D.M., Luckenback, M.W., Rodi, A.J., 1993. Abundance-biomass comparison ABC method: effects of an estuarine gradient, anoxic/hypoxic events and contaminated sediment. Marine Biology 116, 507-518.

Dauvin, J.C., Ruellet, T., Desroy, N., Janson, A.L., 2007. The ecological quality status of the Bay of Seine and the Seine estuary: use of biotic indices, Marine Pollution Bulletin 55, 241-257.

Devlin, M., Painting, S., Best, M., 2007. Setting nutrient thresholds to support an ecological assessment based on nutrient enrichment, potential primary production and undesirable disturbance. Marine Pollution Bulletin 55, 65-73. 
Díaz, R.J., Solan, M., Valente, R.M., 2004. A review of approaches for classifying benthic habitats and evaluating habitat quality. Journal of Environmental Management 73, 165-181.

Dixon, I.M.T., Moore, P.G., 1997. A comparative study of the tubes and feeding behaviour of eight species of corophioid Amphipoda and their bearing on phylogenetic relationships within the Corophioidea. Philosophical transactions of the Royal Society of London 352, 93-112.

Dolbeth, M., Cardoso, P.G., Ferreira, S.M., Verdelhos, T., Raffaelli, D., Pardal, M.A., 2007. Anthropogenic and natural disturbance effects on a macrobenthic estuarine community over a 10-year period. Marine Pollution Bulletin 54, 576-585.

EC, 2000. Directive 2000/60/EC of the European Parliament and of the Council establishing a framework for community action within the field of water policy PE-CONS 3639/1/00, $72 \mathrm{p}$.

EC, 2008. Directive 2008/56/EC of the European Parliament and of the Council of 17 June 2008 establishing a framework for community action in the field of marine environmental policy (Marine Strategy Framework Directive). Official Journal of the European Union, 22p.

Elliot, M., Quintino, V., 2007. The Estuarine Quality Paradox, Environmental Homeostasis and the difficulty of detecting anthropogenic stress in natural stressed áreas. Marine Pollution Bulletin 54, 640-645.

Ferreira, S.M., Pardal, M.A., Lillebø, A.I., Cardoso, P.G., Marques, J.C., 2004. Population dynamics of Cyathura carinata (Isopoda) in a eutrophic temperate estuary. Estuarine Coastal and Shelf Science 61, 669-677.

García-Arberas, L., Rallo, A., 2002. Life cycle, demography and secondary production of the polychaete Hediste diversicolor in a non-polluted estuary in the Bay of Biscay. Marine Ecology 23, 237-251.

Gaston, G.R., Rakocinski, C.F., Brown, S.S., Cleveland, C.M., 1998. Trophic function in estuaries: response of macrobenthos to natural and contaminant gradients. Marine Freshwater Research 49, 833-846.

Gray, J.S. 1997. Marine biodiversity: patterns, threats and conservation needs. Biodiversity and Conservation 6, 153-175.

Jørgensen, S.E., 2000. Principles of pollution abatement. Elsevier, Oxford, 520p.

Jørgensen, S.E., Ladegaard, N., Debeljak, M., Marques, J.C. 2005. Calculations of exergy for organisms. Ecological Modelling 185, 165-175.

Labrune, C., Amouroux, J.-M., Sarda, R., Dutrieux, E., Thorin, S., Rosenberg, R., Grémare, A., 2005. Characterization of the ecological quality of the coastal Gulf of Lions (NW Mediterranean). A comparative approach based on three biotic indices. Marine Pollution Bulletin 52, 34-47. 
Leston, S., Lillebø, A.I., Pardal, M.A. 2008. The response of primary producer assemblages to mitigation measures to reduce eutrophication in a temperate estuary. Estuarine Coastal and Shelf Science 77, 688-696.

Lillebø, A.I., Neto, J.M., Martins, I., Verdelhos, T., Leston, S., Cardoso, P.G., Ferreira, S.M., Marques, J.C., Pardal, M.A., 2005. Management of a shallow temperate estuary to control eutrophication: the effect of hydrodynamics on the system nutrient loading. Estuarine Coastal and Shelf Science 65, 697-707.

Lillebø, A.I., Teixeira, H., Pardal, M.A., Marques, J.C., 2007. Apllying quality status criteria to a temperate estuary before and after mitigation measures to reduce eutrophication symptoms. Estuarine, Coastal and Shelf Science 72, 177-187.

Livingston, R.J., 2003. Trophic organization in Coastal Systems. CRC Press LLC, Florida, 388 p.

Lopes, R.J., Pardal, M.A., Múrias, T., Cabral, J.A., Marques, J.C., 2006. Influence of macroalgal mats on abundance and distribution of dunlin Calidris alpina in estuaries: a long termapproach. Marine Ecology and Progress Series 323, 11-20.

Mackey, R.L., Currie, D.J., 2001. The diversity-disturbance relationship: is it generally strong and peaked? Ecology 82 (12), 3479-3492.

Margalef, R., 1969. Perspectives in Ecological Theory. The University of Chicago Press. Chicago, $111 \mathrm{p}$.

Marques, J.C., Pardal, M.A., Nielsen, S.N., Jørgensen, S.E., 1997. Analysis of the properties of exergy and biodiversity along an estuarine gradient of eutrophication. Ecological Modelling 102,155-167.

Marques, J.C., Nielsen, S.N., Pardal, M.A., Jørgensen, S.E., 2003. Impact of eutrophication and river management within a framework of ecosystem theories. Ecological Modelling 166,147168.

Marques, J.C., Neto, J.M., Patrício, J., Pinto, R., Teixeira, H., Veríssimo, H., 2007 Monitoring the Mondego estuary. Anthropogenic changes and their impact on ecological quality. Preliminary results from the first assessment of the effects of reopening the communication between the North and South arms on the eutrophication state of the system. Final Report, January 2007. IMAR/INAG, $87 \mathrm{pp}$.

Martins, I., Neto, J.M., Fontes, M.G., Marques, J.C., Pardal, M.A., 2005. Seasonal variation of short-term survival of Zostera noltii transplants in a declining meadow in Portugal. Aquatic Botany 82/2, 132-142.

Mejer, H., Jørgensen, S.E., 1979. Exergy and ecological buffer capacity. In Jørgensen, S.E. (ed). State of art in ecological modeling. Copenhagen and Pergamon Press, Oxford, 829-846 p. 
Morton, B., 1983. Feeding and digestion in Bivalvia. In: Salenddin AS, Willeur KM (eds) The Mollusca (vol 5, part 2). Academic Press, London, 500 p.

Muxika, I., Borja, Á., Bald, J. 2007. Using historical data, expert judgment and multivariate analysis in assessing reference conditions and benthic ecological status, according to the European Water Framework Directive, Marine Pollution Bulletin 55, 16-29.

Pardal, M.A., Marques, J.C., Metelo, I., Lillebø, A.I., Flindt, M.R., 2000. Impact of eutrophication on the life cycle, population dynamics and production of Ampithoe valida (Amphipoda) along an estuarine spatial gradient (Mondego estuary, Portugal). Marine Ecology Progress Series 196, 207-219.

Pardal, M.A., Cardoso, P.G., Sousa, J.P., Marques, J.C., Raffaelli, D., 2004. Assessing environmental quality: a novel approach. Marine Ecology Progress Series 267, 1-8.

Patrício, J., Marques, J.C., 2006. Mass balanced models of the food web in three areas along a gradient of eutrophication symptoms in the south arm of the Mondego estuary (Portugal). Ecological Modelling 197, 21-34.

Pearson, T.H., Rosenberg, R., 1978. Macrobenthic succession in relation to organic enrichment and pollution of the marine environment. Oceanography and Marine Biology: an Annual Review 16, 229-331.

Philippart, C.J., 1995. The Effect of periphyton grazing by Hydrobia ulvae on the growth of Zostera noltii on a tidal flat in the Dutch Wadden Sea. Marine Biology 122, 431-437.

Pinto, R., Patrício, J., Baeta, A., Fath, B.D., Neto, J.M., Marques, J.C., 2009. Review and evaluation of estuarine biotic indices to assess benthic condition. Ecological Indicators 9,125.

Quintino, V., Elliot, M., Rodrigues, A.M., 2006. The derivation, performance and role of univariate and multivariate indicators of benthic change: case studies at different spatial scales. Journal of Experimental Marine Biology and Ecology 330, 368-382.

Raffaelli, D.G., Raven, J.A., Poole, L.J. 1998. Ecological impact of green macroalgal blooms. Oceanography and Marine Biology Annual Review 16, 229-311.

Rosenberg, R., Blomqvist, M., Nilsson, H.C., Cederwall, H., Dimming, A. 2004. Marine quality assessment by use of benthic species-abundance distribution: a proposed new protocol within the European Union Water Framework Directive. Marine Pollution Bulletin 49, 728739.

Riera, P., Stal, L.J., Nieuwenhuize, J., Richard, P., Blanchard, G., Gentil, F., 1999. Determination of food sources for benthic invertebrates in a salt marsh (Aiguillon Bay, France) by carbon 
and nitrogen stable isotopes: importance of locally produced sources. Marine Ecology Progress Series 187, 301-307.

Salas, F., Patrício, J., Marques, J.C., 2006. Ecological indicators in coastal and estuarine environmental quality assessment. A user- friendly guide for practitioners. Coimbra University press, $165 \mathrm{p}$.

Shannon, C.E., Weaver, W., 1963. The Mathematical theory of communication. University of Illinois Press.

Simboura, N., Panayotidis, P., Papathanassiou, E., 2005. A synthesis of the biological quality elements for the implementation of the European Water Framework Directive in the Mediterranean ecoregion: The case of Saronikos Gulf. Ecological Indicators 5, 253-266.

Solis-Weiss, V., Aleffi, F., Bettoso, N., Rossini, P., Orel, G., Fonda-Umani, S., 2004. The Effects of industrial and urban pollution on the benthic macrofauna in the Bay of Muggia (industrial port of Trieste, Italy). Science of Total Environment 328, 247-263.

Teixeira, H., Salas, F., Neto, J.M., Patrício, J., Pinto, R., Veríssimo, H., García-Charton, J.A., Marcos, C., Pérez-Ruzafa, A., Marques, J.C., 2008. Ecological indices tracking distinct impacts along disturbance-recovery gradients in a temperate NE Atlantic Estuary - guidance on reference values. Estuarine Coastal and Shelf Science 80(1), 130-140.

Warwick, R.M., Clarke, K.R., 1993. Comparing the severity of disturbance: a meta-analysis of marine macrobenthic community data. Marine Ecology Progress Series 92(3), 221-231.

Warwick, R.M., Clarke, K.R., 1995. New 'biodiversity' measures reveal a decrease in taxonomic distinctness with increasing stress. Marine Ecology Progress Series 129, 301-305.

Weisberg, S.B., Thompson, B., Ranasinghe, J.A., Montagne, D.E., Cadien, D.B., Dauer, D.M., Diener, D., Oliver, J. Reish, D.J., Velarde, R.G., Word, J.Q. ,2008. The level of agreement among experts applying best professional judgment to assess the condition of benthic infaunal communities. Ecological Indicators 8, 389-394.

Word, J.Q., 1979. The Infaunal Trophic Index. California Coastal Water Research Project Annual Report 19-39.

Word, J.Q., 1990. The Infaunal Trophic Index, a functional approach to benthic community analyses. PhD Dissertation, University of Washington, Seattle, Washington, USA. 
717 Table 1. Ecological indicators: algorithms and ecological classification.

Indicator

Algorithm/ Explanation

Classification

1. Species as indicators

AZTI's Marine Biotic Index

(Borja et al. 2000)

$A M B I=\frac{\{(0 \times \% G I)+(1,5 \times \% G I I)+(3 \times \% G I I I)+(4,5 \times \% G I V)+(6 \times \% G V)\}}{100}$

I. Species very sensitive to organic enrichment and present under unpolluted conditions; II. Species indifferent to enrichment, always in low densities with nonsignificant variations with time; III. Species tolerant to excess of organic matter enrichment; IV. Second-order opportunist species, mainly small sized polychaete; V. First-order opportunist species, essentially deposit-feeders

\section{Diversity}

\section{Average Taxonomic Diversity}

(Warwick and Clarke 1995)

Average Taxonomic

\section{Distinctness}

(Warwick and Clarke 1995)

Total Taxonomic Distinctness

(Warwick and Clarke 1995)

$$
\begin{aligned}
\Delta & =\left\lfloor\sum \sum_{i<j} \omega_{i j} x_{i} x_{j}\right\rfloor /[n(n-1) / 2] \\
\Delta^{*} & =\left[\sum \sum_{i<j} \omega_{i j} x_{i} x_{j}\right] /\left[\sum \sum \delta_{i<j} x_{i} x_{j}\right]
\end{aligned}
$$

$$
s \Delta^{+}=\left[\Sigma_{i}\left[\left(\sum_{i \neq j} \omega_{i j}\right) /(s-1)\right]\right.
$$

$\begin{array}{lr}\text { Normal } & 0-1.2 \\ \text { Slightly polluted } & 1.2-3.2 \\ \text { Moderately polluted } & 3.2-5.0 \\ \text { Highly polluted } & 5.0-6.0 \\ \text { Azoic } & 6.0-7.0\end{array}$

Slightly polluted $\quad \begin{array}{r}0-1.2 \\ \text { S. }\end{array}$

thelly polluted -3.5 .0$

Azoic $\quad 6.0-7.0$
Higher value, higher biodiversity - on average species in the assemblage are not closely (phylogenetic) related

$x_{i}$ : abundance of the $i$ th of $S$ species observed; $n\left(=\sum_{i} x_{i}\right)$ : total number of individuals in the sample; $\omega_{i j}$ : "distinctness weight" given to the path length linking species $i$ and $j$ in the taxonomy

\section{Berger-Parker Index}

(Berger and Parker 1970)

Margalef Index
(Margalef 1969)

\section{Shannon-Wiener Index}

(Shannon and Weaver 1963)

$$
D=n_{\max } / N
$$

Low diversity $\quad 1$ High diversity 0

$n_{\text {max }}$ : number of individuals of the most abundant species; $\mathrm{N}$ : total number of individuals

$D=(S-1) / \operatorname{Ln}(N)$
$S$ :number of species found; $N$ : total number of individuals
$H^{\prime}=-\sum p_{i} \log _{2} p_{i}$

$p_{i}$ : proportion of abundance of species $i$ in a community were species proportions are $p_{i}, p_{2}, p_{3} \ldots p_{n} ; S:$ number of species found

\section{Ecological strategies}

\section{Infaunal Trophic Index}

(Word 1979)

$$
I T I=100-100 / 3\left(0 n_{1}+1 n_{2}+2 n_{3}+3 n_{4}\right) /\left(n_{1}+n_{2}+n_{3}+n_{4}\right)
$$

Macrofauna groups: (1) suspension feeders; (2) interface feeders; (3) surface deposit feeders; (4) subsurface deposit feeders

$n_{1}, n_{2}, n_{3}, n_{4}$ : number of individuals in each of the above mentioned groups Low diversity $\quad 0$

High diversity $\quad \geq 5$

Low diversity Low value

\section{Thermodynamically oriented}

\section{Eco-Exergy}

(Mejer and Jørgensen 1979)

Specific Eco-Exergy

(Jørgensen 2000)

$$
E X=T \times \sum \beta_{i} \times C_{i}
$$

$T$ : absolute temperature; $C_{i}$ : concentration in the ecosystem of component $i$ (e.g. biomass of a given taxonomic group or functional group); $i$ : factor able to express roughly the quantity of information embedded in the genome of the organisms

$$
\text { SpEX }=\text { Exergy } / \text { Total biomass }
$$

Community dominated by: Group $1 \quad>78$

Group $2 \quad 58-77$

Group $3 \quad 25-57$

Group $4<24$ 
719 Table 2. Trophic classification of taxa contributing the top $80 \%$ of the abundance recorded

720 in the two studied intertidal sites of the Mondego estuary, from 1985 to 2002. Trophic

721 group assigned according to references. 1: suspension feeders; 2: suspension and

722 surface-detritus feeders; 3 : surface deposit feeders; 4: subsurface deposit feeders.

\begin{tabular}{|c|c|c|c|c|c|}
\hline $\begin{array}{c}\text { Trophic } \\
\text { Group }\end{array}$ & Taxa & References & $\begin{array}{c}\text { Trophic } \\
\text { Group }\end{array}$ & Taxa & References \\
\hline \multirow{3}{*}{1} & Cerastoderma & Morton 1983 & \multirow{7}{*}{3} & Carcinus maenas & Riera et al. 1999 \\
\hline & Spio & Dauer et al. 1981 & & Crangon crangon & Ansell et al. 1999 \\
\hline & Scrobicularia plana & Riera et al. 1999 & & Cyathura carinata & Ferreira et al. 2004 \\
\hline \multirow{9}{*}{2} & Alkmaria romijni & $\begin{array}{l}\text { Word } 1990 \\
\text { (Ampharetinae) }\end{array}$ & & Hediste diversicolor & Garcia-Arberas \& Rallo 2002 \\
\hline & Ampithoe & Dixon \& Moore 1997 & & Hydrobia ulvae & Philippart 1995 \\
\hline & Corophium & Word 1990 & & Diptera & Livingston 2003 \\
\hline & Chaetozone setosa & Word 1990 & & Mysta picta & Solis-Weiss et al. 2004 \\
\hline & Heteromastus & Word 1990 & \multirow{5}{*}{4} & Capitella & Word 1990 \\
\hline & Mediomastus & Word 1990 & & Oligochaeta sp1 & Word 1990 \\
\hline & Melita palmata & Word 1990 & & Tetrastemma & Barnes \& de Villiers 2000 \\
\hline & Pygospio elegans & Word 1990 & & \multirow[t]{2}{*}{ Tubificoides } & \multirow[t]{2}{*}{ Gaston et al. 1998} \\
\hline & Streblospio shrubsolii & Word 1990 & & & \\
\hline
\end{tabular}

723

724 
Table 3. Average abundance values (ind. $\mathrm{m}^{-2}$ ) of the species that contributed more than

$72870 \%$ to the difference between periods in the $Z$. noltii and in the bare sediment sites.

\begin{tabular}{|c|c|c|c|}
\hline & Before the interruption & During the interruption & $\begin{array}{l}\text { After the } \\
\text { experimental opening }\end{array}$ \\
\hline \multicolumn{4}{|l|}{ Zostera noltii site } \\
\hline Hediste diversicolor & 1189 & 19 & 523 \\
\hline Tubificidae & 0 & 2944 & 714 \\
\hline Alkmaria romijni & 204 & 993 & 443 \\
\hline Heterosmastus filiformis & 265 & 550 & 357 \\
\hline Capitela capitata & 114 & 241 & 92 \\
\hline Chaetozone setosa & 0 & 1756 & 31 \\
\hline Hydrobia ulvae & 1960 & 80691 & 41862 \\
\hline Scrobicularia plana & 596 & 1023 & 724 \\
\hline Melita palmata & 83 & 336 & 75 \\
\hline Cyathura carinata & 271 & 217 & 173 \\
\hline Oligochaete & 0 & 220 & 100 \\
\hline Streblospio shrubsolii & 60 & 349 & 138 \\
\hline Cerastoderma edule & 13 & 519 & 74 \\
\hline \multicolumn{4}{|l|}{ Bare sediment site } \\
\hline Hediste diversicolor & 523 & 50 & 265 \\
\hline Hydrobia ulvae & 1166 & 27192 & 5573 \\
\hline Alkmaria romijni & 93 & 6076 & 1483 \\
\hline Cyathura carinata & 638 & 2043 & 2177 \\
\hline Scrobicularia plana & 319 & 2347 & 2763 \\
\hline Amphicteis gunneri & 106 & 0 & 0 \\
\hline
\end{tabular}


Table 4. Summary of the ecological indicators trends obtained for the $Z$. noltii and bare sediment sites, considering "during the interruption" and "after the experimental opening" (after) periods. In bold are the values that are compliant with a priori established classification criteria.

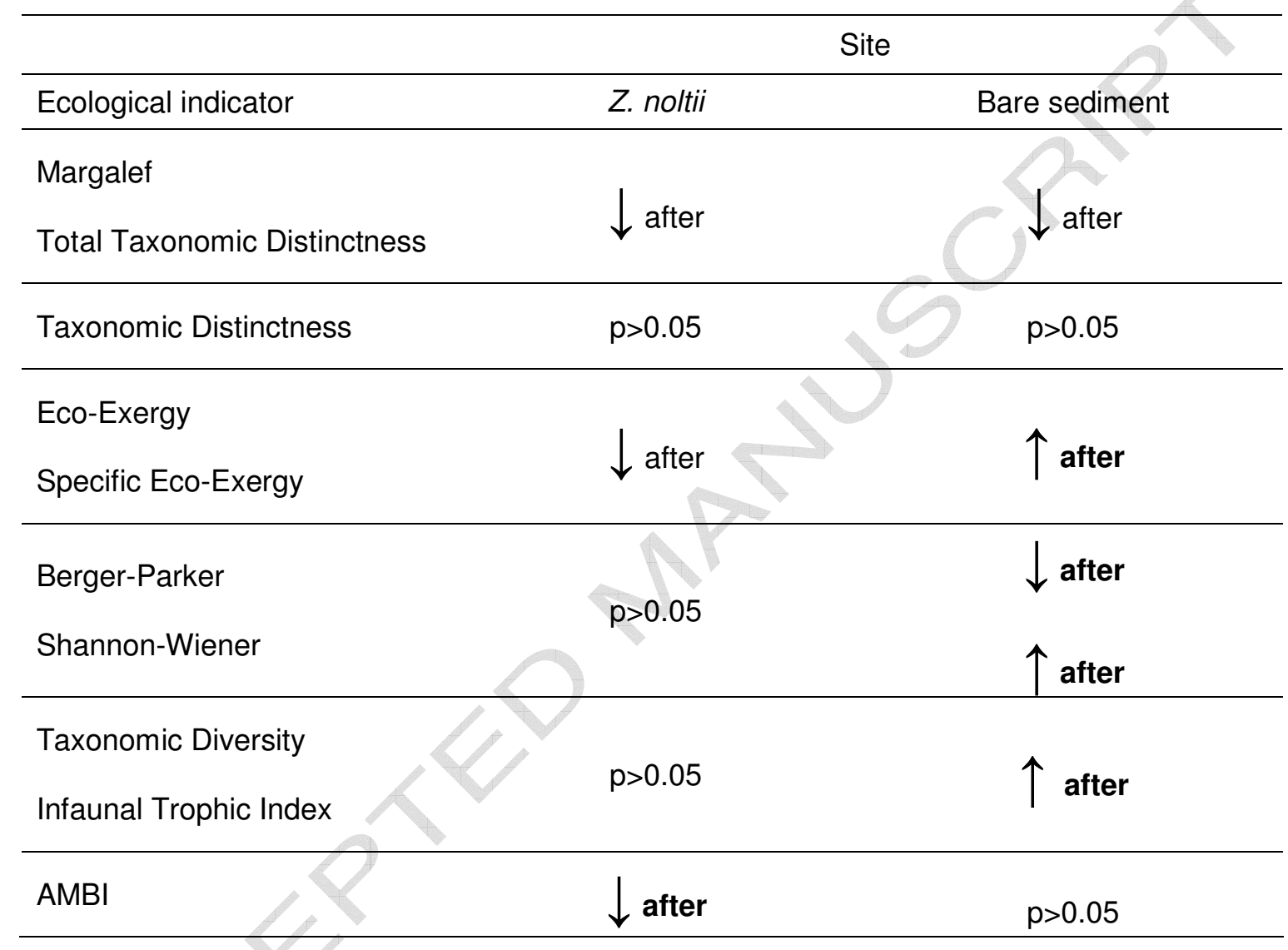




\section{Figures captions}

Figure 1. Mondego estuary. Location of the two intertidal sampling sites (black circles): Z. noltii site and bare sediment site and position of the connection area between the North and South arms (open circle). NA-north arm, SA-south arm.

Figure 2. Temporal changes of $Z$. noltii meadows' area (ha) and biomass (g AFWD m

$\left.{ }^{-2}\right)$, green macroalgae biomass ( $\mathrm{g}$ AFWD $\mathrm{m}^{-2}$ ) and the connection width between the two estuarine arms. Black areas correspond to $Z$. noltii site, bare sediment site and connection between the two arms. NA-north arm, SA-south arm.

Figure 3. Macrofauna A. total abundance, B. total biomass and C. number of species in the $Z$. noltii site and in the bare sediment site, during the study period.

Figure 4. A Two-dimensional, non-metric, multidimensional scaling (nMDS) ordination based on abundance data. A. Z. noltii site and B. bare sediment site, for the three time periods: before the perturbation under assessment (1985 and 1986), period without connection between arms (1993, 1994 and 1995) and after experimental mitigation measures (1999-2002). Each point represents a different time period at the same site. Stress values are shown for each nMDS plot indicating the similarity between the multi-dimensional representation and the 2-dimension plot.

Figure 5. Temporal and spatial variation of different ecological indicators applied to data of the intertidal communities of the South arm of the Mondego estuary, during the study period. 


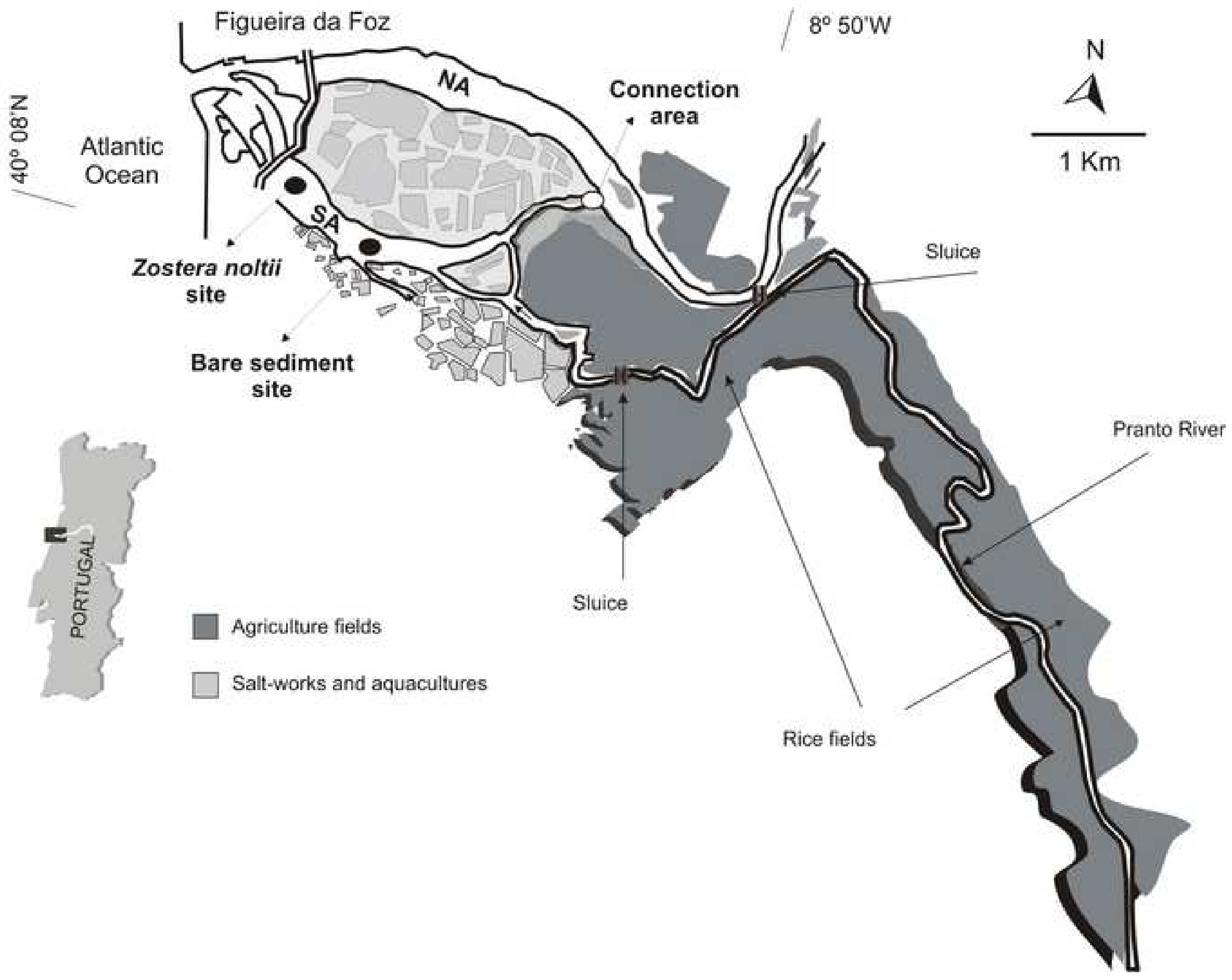




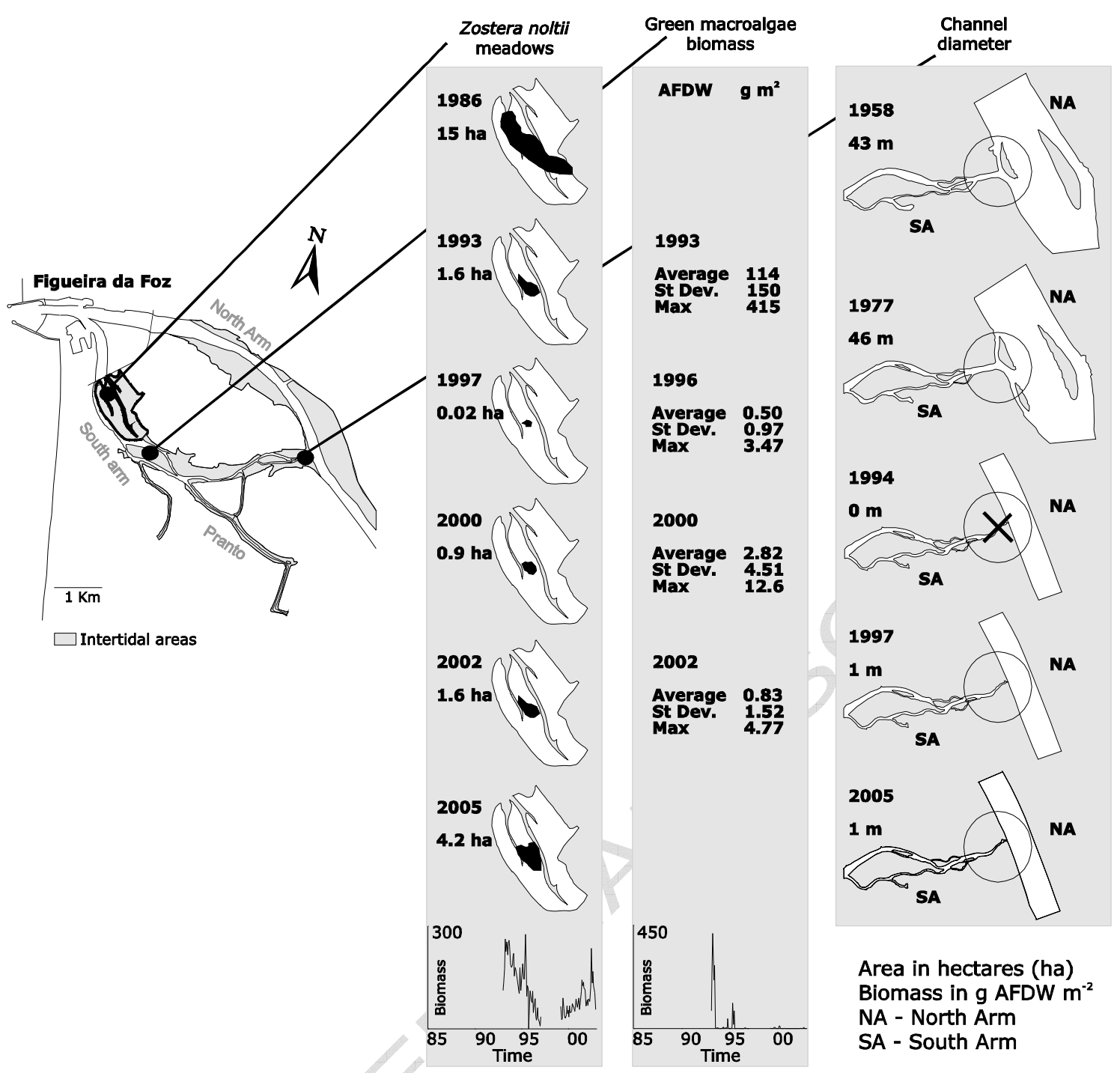




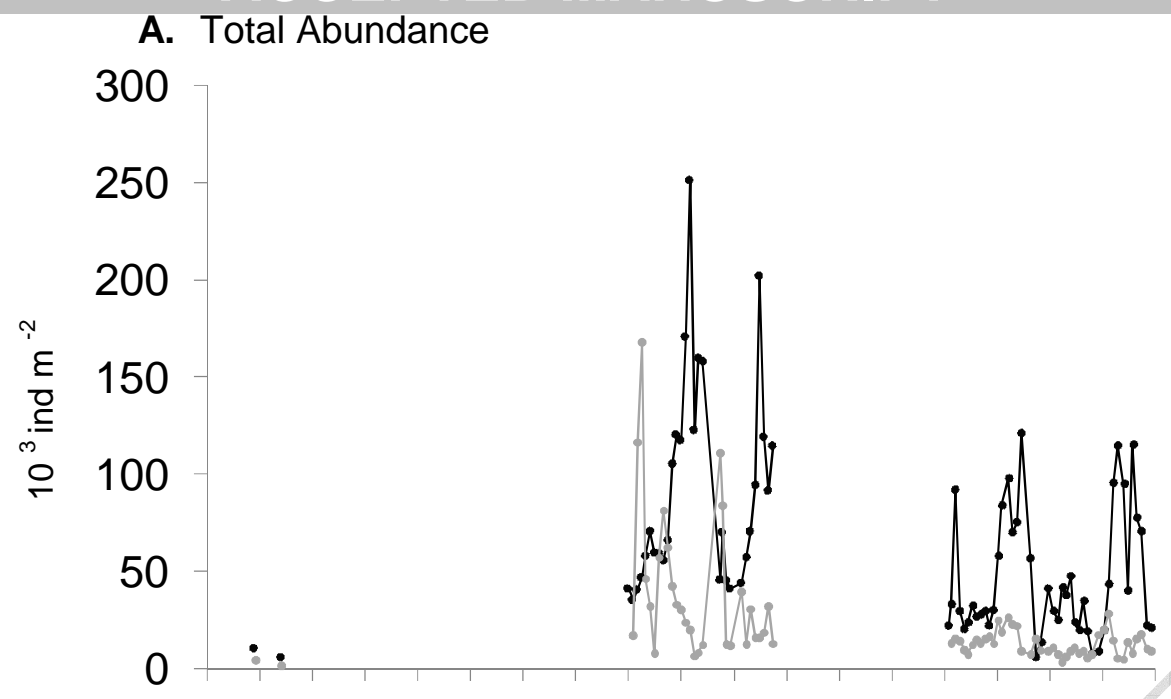

ம

B. Total Biomass
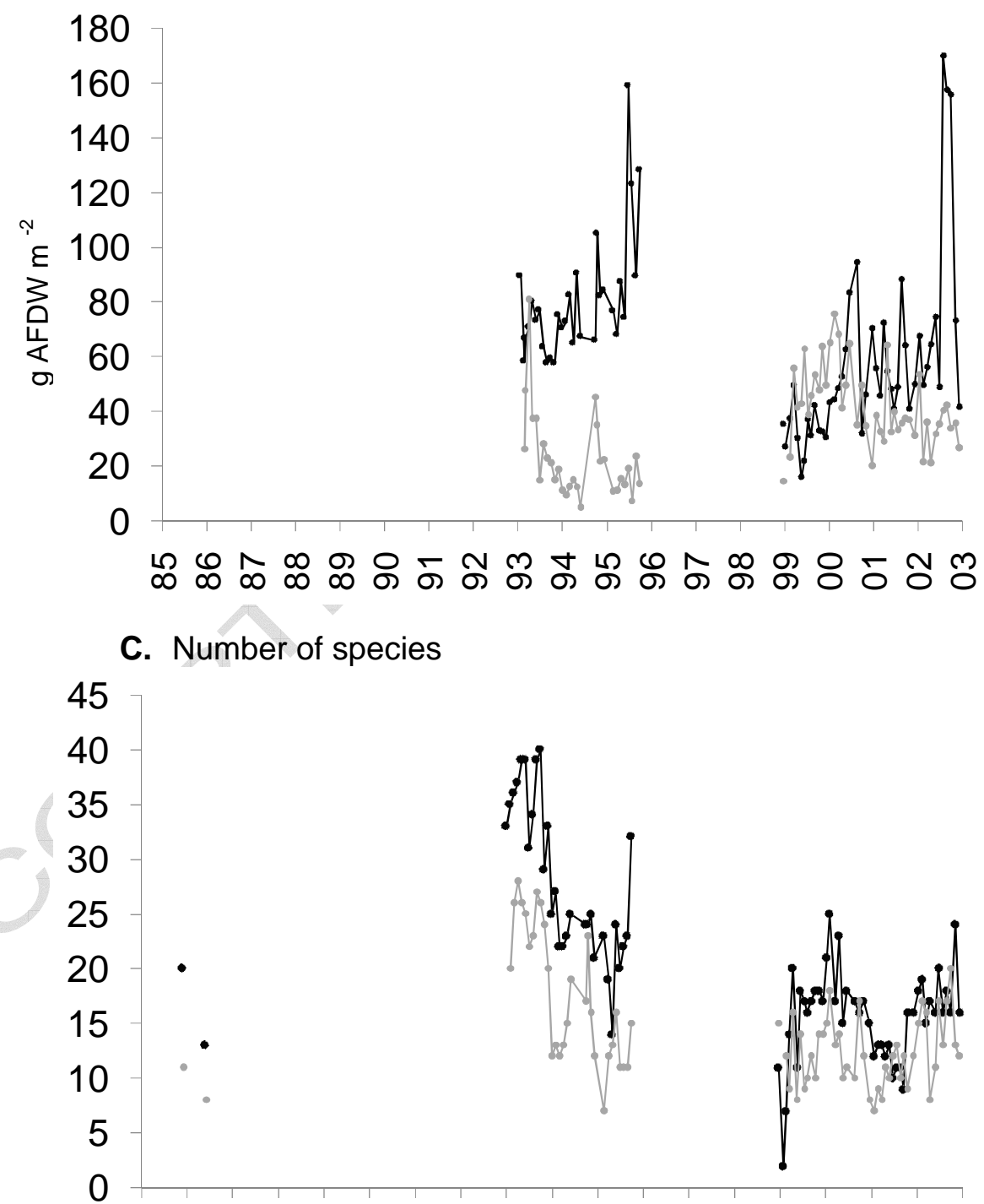

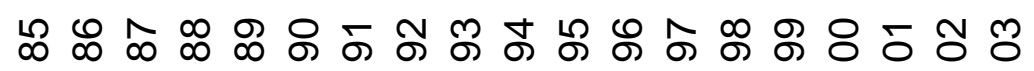

- Zostera noltii site $\circ$ Bare sediment site

Figure 3 
A. Zostera noltii site

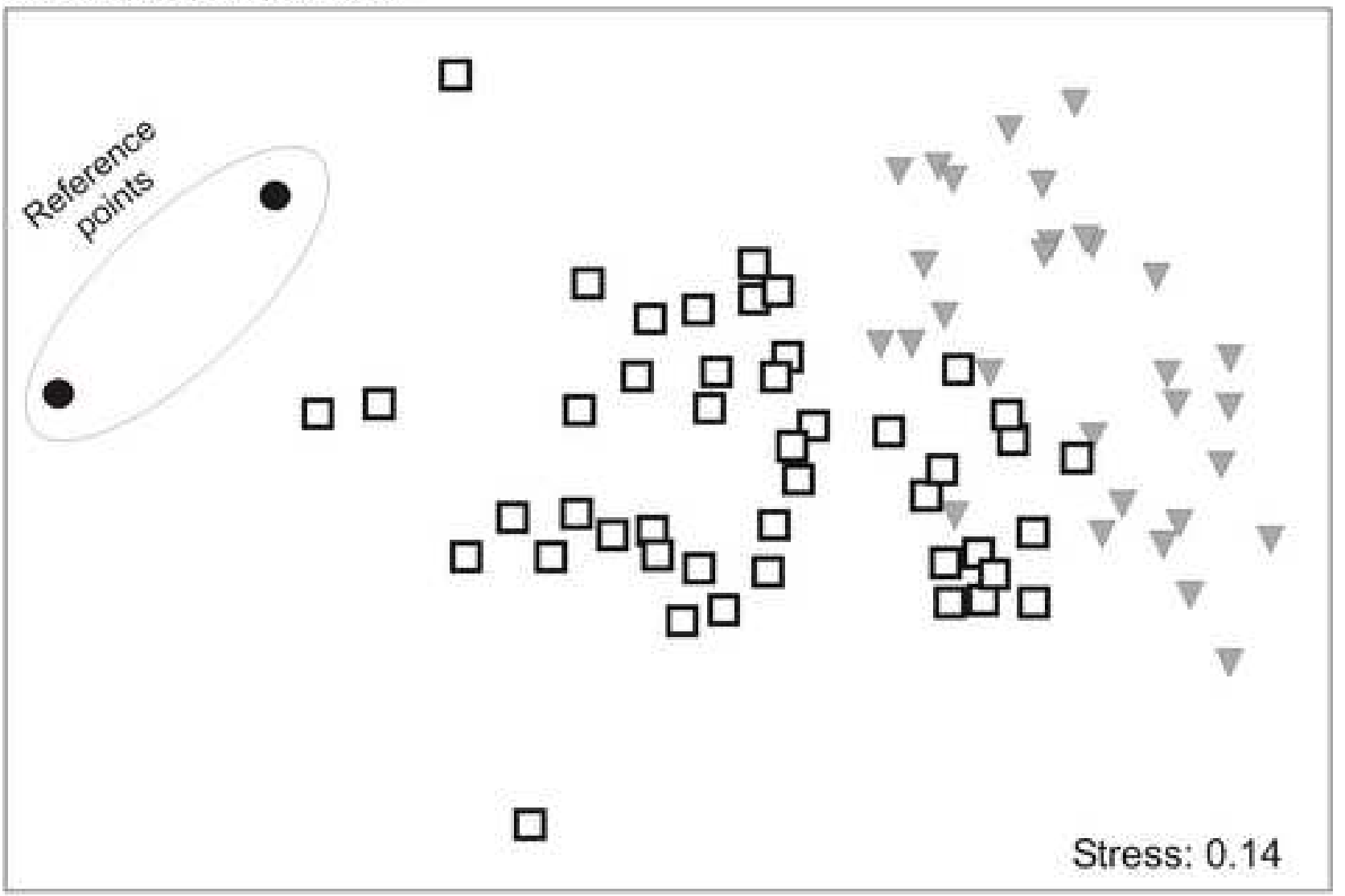

B. Bare sediment site

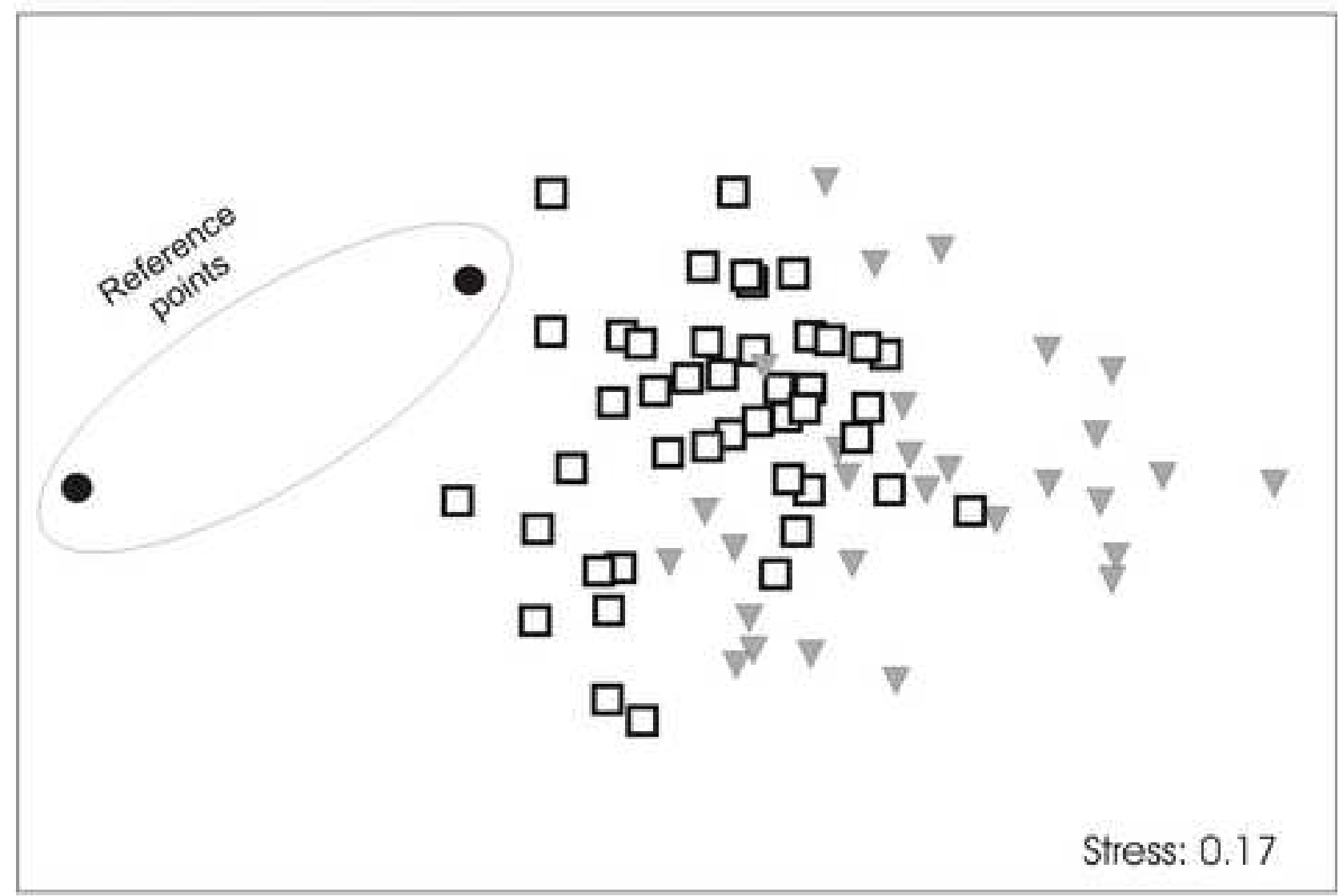

- Before perturbation

$\nabla$ During interruption

After experimental opening 


\section{A. Margalef}

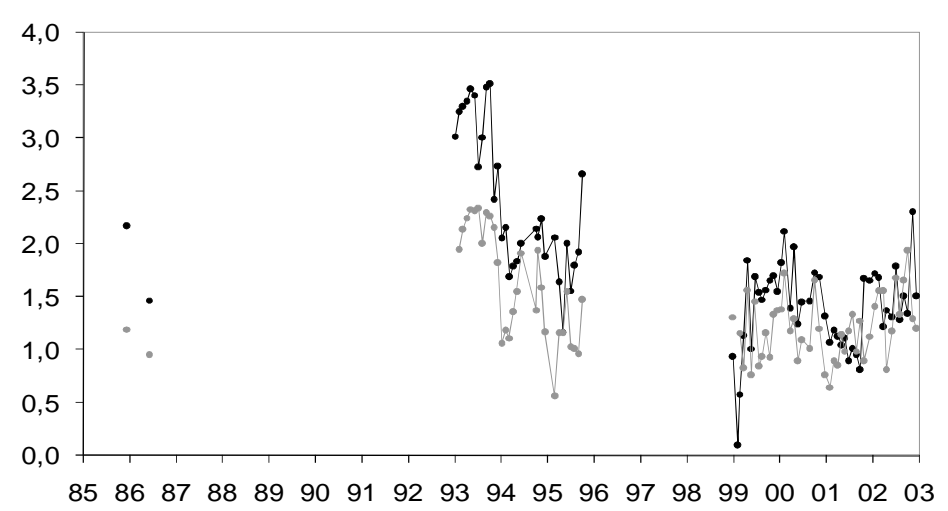

C. Taxonomic Distinctness, $\Delta^{*}$

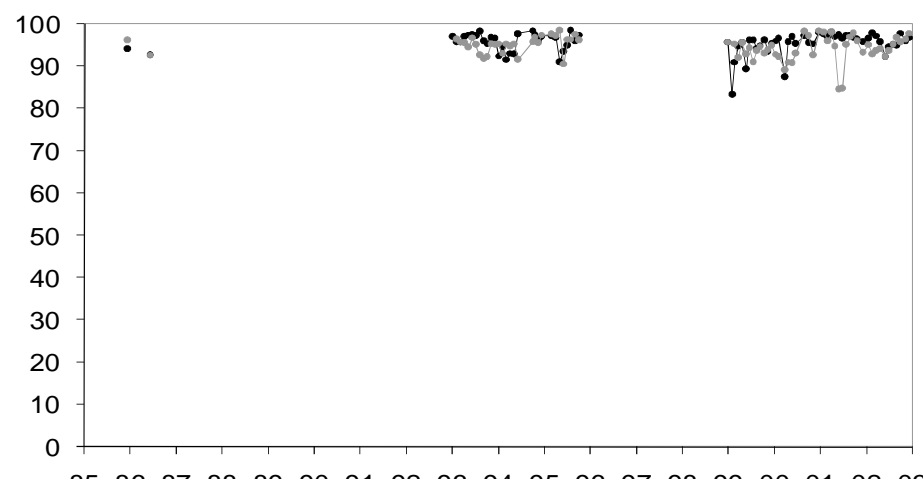

$\begin{array}{lllllllllllllllllll}85 & 86 & 87 & 88 & 89 & 90 & 91 & 92 & 93 & 94 & 95 & 96 & 97 & 98 & 99 & 00 & 01 & 02 & 03\end{array}$

E. Infaunal Trophic Index

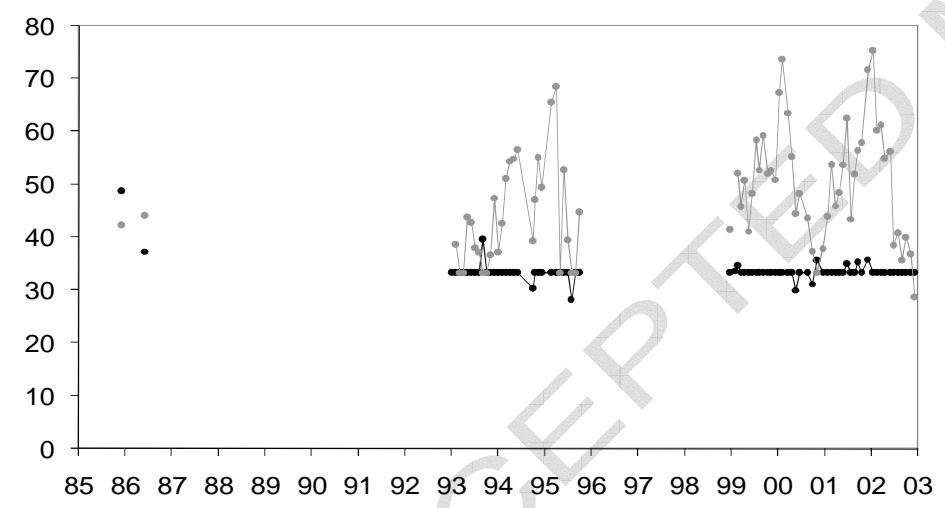

G. Berger-Parker

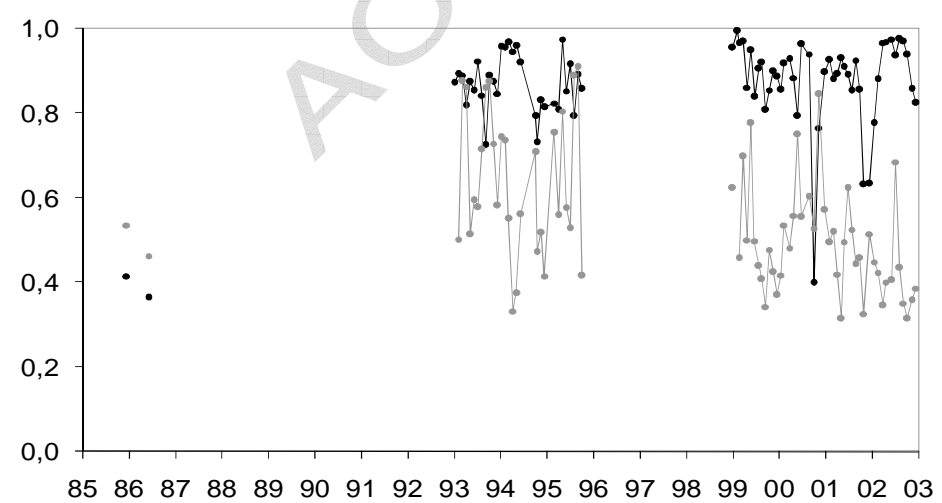

- Zostera noltii site
B. Total Taxonomic Distinctness, $s \Delta^{+}$

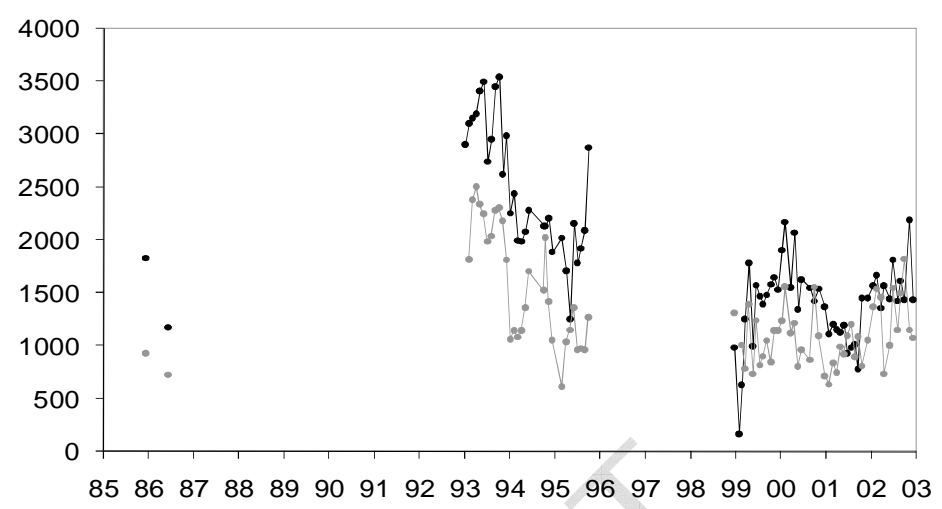

D. Taxonomic Diversity, $\Delta$

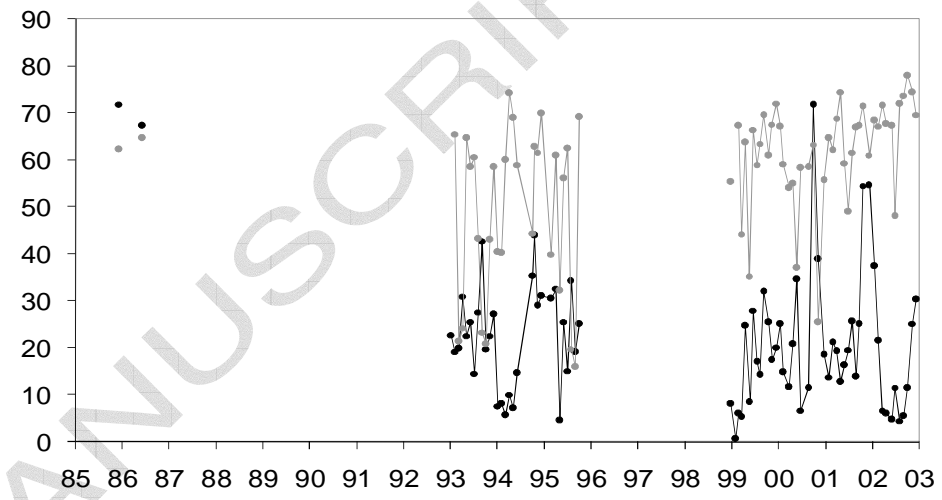

\section{F. Shannon-Wiener}

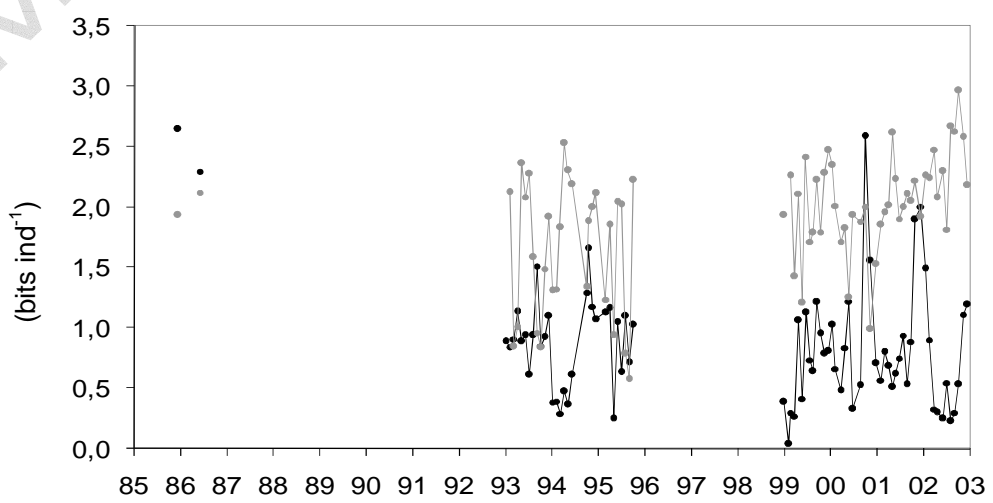

H. $\mathrm{AMBI}$

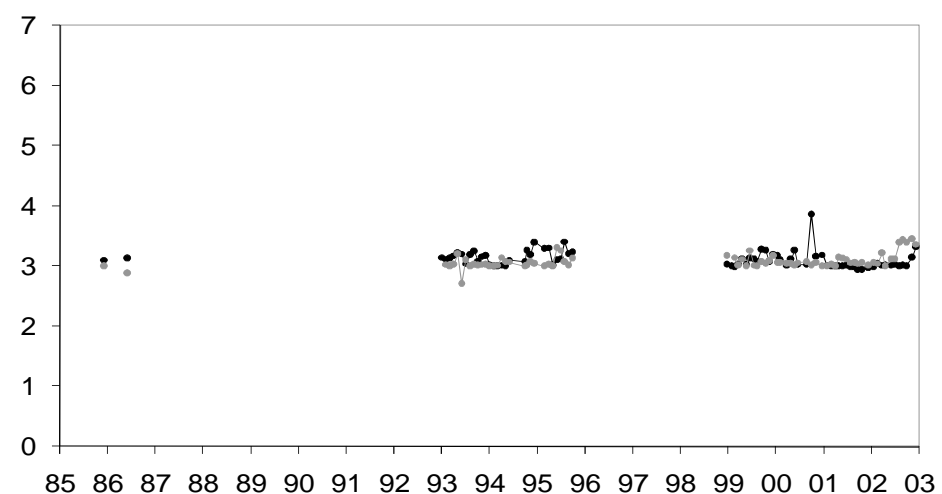

Figure 5 
I. Eco-Exergy (g m ${ }^{-2}$ det.energy.equiv.)

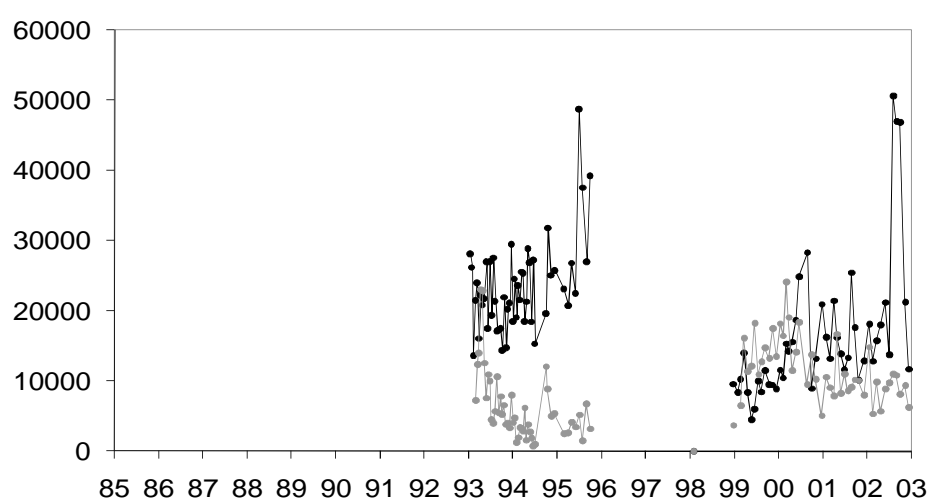

- Zostera noltii site
J. Specific Eco-Exergy (Eco-Exergy/biomass unit)

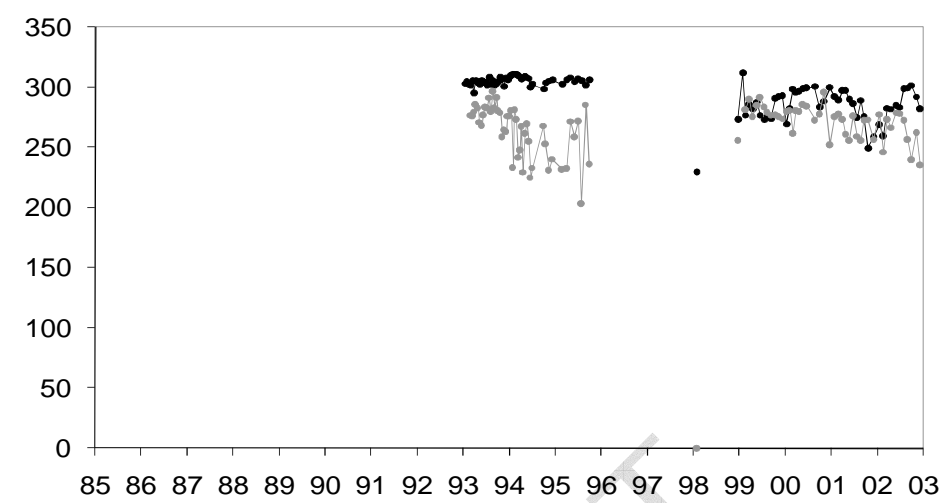

- Bare sediment site

Figure 5 (continued) 